\title{
GLOBAL BANKING NETWORK AND REGIONAL FINANCIAL CONTAGION
}

Cyn-Young Park and Kwanho Shin

NO. 546

May 2018
ADB ECONOMICS WORKING PAPER SERIES 
ADB Economics Working Paper Series

\section{Global Banking Network and Regional Financial Contagion}

Cyn-Young Park and Kwanho Shin

No. 546 | May 2018
Cyn-Young Park (cypark@adb.org) is a Director in the Regional Cooperation and Integration Division (ERCI) of the Economic Research and Regional Cooperation Department, Asian Development Bank. Kwanho Shin (khshin@korea.ac.kr) is a Professor in the Department of Economics, Korea University.

This study was initially prepared for a background paper to provide policy inputs for ERCl's support in global and/regional policy forums. We thank Yasuyuki Sawada for his valuable comments. We also thank Dohoon Kim for his excellent research assistance and Mara Claire C. Tayag for her support in publishing in the ADB ERCD Working Paper Series. 
(C) 2018 Asian Development Bank

6 ADB Avenue, Mandaluyong City, 1550 Metro Manila, Philippines

Tel +632632 4444; Fax +6326362444

www.adb.org

Some rights reserved. Published in 2018.

ISSN 2313-6537 (print), 2313-6545 (electronic)

Publication Stock No. WPS189353-2

DOI: http://dx.doi.org/10.22617/WPS189353-2

The views expressed in this publication are those of the authors and do not necessarily reflect the views and policies of the Asian Development Bank (ADB) or its Board of Governors or the governments they represent.

ADB does not guarantee the accuracy of the data included in this publication and accepts no responsibility for any consequence of their use. The mention of specific companies or products of manufacturers does not imply that they are endorsed or recommended by ADB in preference to others of a similar nature that are not mentioned.

By making any designation of or reference to a particular territory or geographic area, or by using the term "country" in this document, $A D B$ does not intend to make any judgments as to the legal or other status of any territory or area.

This work is available under the Creative Commons Attribution 3.0 IGO license (CC BY 3.0 IGO)

https://creativecommons.org/licenses/by/3.0/igo/. By using the content of this publication, you agree to be bound by the terms of this license. For attribution, translations, adaptations, and permissions, please read the provisions and terms of use at https://www.adb.org/terms-use\#openaccess.

This CC license does not apply to non-ADB copyright materials in this publication. If the material is attributed to another source, please contact the copyright owner or publisher of that source for permission to reproduce it. $\mathrm{ADB}$ cannot be held liable for any claims that arise as a result of your use of the material.

Please contact pubsmarketing@adb.org if you have questions or comments with respect to content, or if you wish to obtain copyright permission for your intended use that does not fall within these terms, or for permission to use the ADB logo.

Notes:

In this publication, “\$” refers to United States dollars.

ADB recognizes "Korea" as the Republic of Korea.

Corrigenda to ADB publications may be found at http://www.adb.org/publications/corrigenda. 


\section{CONTENTS}

TABLES AND FIGURES

ABSTRACT V v v v v v

$\begin{array}{ll}\text { I. INTRODUCTION } & 1\end{array}$

II. BILATERAL BANK CLAIMS DATA AND THEIR REGIONAL DECOMPOSITION 3

III. REGIONAL CONTAGION OF VULNERABILITIES 9

IV. EMPIRICAL FINDINGS

$\begin{array}{lll}\text { V. CONCLUSION } & 26\end{array}$

$\begin{array}{ll}\text { APPENDIX } & 28\end{array}$

$\begin{array}{ll}\text { REFERENCES } & 31\end{array}$ 


\section{TABLES AND FIGURES}

\section{TABLES}

$1 \quad$ Summary Statistics $\quad 13$

2 Contagion Effects in Capital Outflows in the Region 15

3 Contagion Effects in Capital Outflows Due to Exposures of the Banking Sector 20

$4 \quad$ Contagion Effects in Capital Outflows Due to Exposures of Short-Term Claims: 24

The Consolidated Banking Statistics on Immediate Counterparty Basis

A1.1 Reporting Economies and Counterparty Emerging Market Economies by Region 28

A1.2 Definitions of Variables and Data Sources

\section{FIGURES}

1 Regional Shares of Total Claims in East Asia 5

2 Regional Shares of Total Claims in Central and South America 6

3 Regional Shares of Total Claims for Individual Emerging Market Economies, East Asia 7 


\begin{abstract}
This paper investigates and tests the role of regional exposures in financial contagion from advanced to emerging market economies through the global banking network using data on cross-border bilateral bank claims and liability positions. We first examine whether an economy can become more susceptible to capital outflows, regardless of its own bank exposures, if economies in the same region are heavily exposed to crisis countries. Second, we test whether the same region lenders tend to reduce exposures to the emerging market borrowers less than do different region lenders during crises. Using bilateral data from the Bank for International Settlements international banking statistics, we obtain evidence for both hypotheses. First, we find that direct exposures of a country's own and the overall region's banking sectors to crisis-affected countries are systematically related to bank capital outflows during the global financial crisis. Also, some of our empirical results indicate that an emerging economy's financial vulnerability can be influenced by its region's indirect exposures to crisis countries. Second, a further analysis suggests more favorable behavior of the same region lender toward emerging economies during crisis.
\end{abstract}

Keywords: capital outflows, contagion, direct/indirect exposures, global financial crisis, regional

JEL codes: E44, F15, F21, F34, F38, F42, F62 


\section{INTRODUCTION}

As advanced countries start to normalize monetary policies, concerns arise about the vulnerability of emerging market economies (EMEs). A number of emerging Asian economies have seen particularly large capital inflows and rising asset prices in recent years, leading to rapid credit growth. Elevated asset valuations combined with high corporate and household leverage could bring corrections to overvalued markets during the global tightening cycle. 'Overall, many Asian EMEs maintain sound macroeconomic fundamentals such as healthy current account surpluses, moderate fiscal deficits and public debt levels, low external short-term borrowing and sizable foreign reserves. Yet, concerns remain that EMEs are vulnerable to sudden reversals in capital flows in an increasingly interconnected global financial system and banking network (ADB 2017).

Crisis episodes highlight the volatility of capital, particularly of cross-border banking flows. During the Asian financial crisis in 1997, crisis-affected Asian countries suffered sudden reversals in capital flows, driven especially by banking outflows. During the global financial crisis in 2008, many Asian EMEs again simultaneously experienced a sharp increase in gross capital outflows, driven largely by retrenchments in global cross-border bank lending activities, even though the crisis did not originate from these economies. These episodes suggest that financial crises are contagious and banking flows can be particularly susceptible to the perception of market risks. The spread of financial risks or perception of such risks across neighboring economies during crisis is also noticeable.

A strand of empirical studies has examined the determinants (push and pull factors) of capital flows (Kalemli-Ozcan, Papaioannou, and Peydró 2013; Kaminsky, Reinhart, and Végh 2004; Cerutti, Claessens, and Puy 2015; Cerutti, Claessens, and Ratnovski 2017; Choi and Furceri 2018). Their findings suggest that determinants of capital flows can be considerably different across instruments and across the type of flows considered, either net or gross. While both push and pull factors generally play a role for capital flows, the determinants can also be very different between normal and crisis times. In particular, the empirical findings show the significant effects of economic and policy shocks and/or uncertainties on cross-border capital flows, especially short-term portfolio and banking flows, during crisis. But most empirical studies do not explicitly model these shocks and uncertainties and treat them as exogenous. Without clear explanation for what these shocks and uncertainties are and where they came from, past studies are also silent about mechanisms to explain how they transmit across borders.

Recent studies noted that the growing global financial network is important in the dissemination and spillover of financial risks. Acemoglu, Ozdaglar, and Tahbaz-Salehi (2015) argue that the density of a financial network can influence the magnitude of financial contagion. They elaborate: "when the magnitude of negative shocks affecting financial institutions are sufficiently small, a more densely connected financial network (corresponding to a more diversified pattern of interbank liabilities) enhances financial stability. However, beyond a certain point, densely interconnected financial networks serve as a mechanism for the propagation of shocks, leading to a more fragile financial system." A number of studies surveyed in Allen and Babus (2009) also used the network theory to explain financial contagion. Claessens and Forbs (2004) added a review of the analytical and empirical literature on early studies on contagion.

An increasing number of studies are paying more attention to the cross-border banking network. For example, Hahm, Shin, and Shin (2013) find that a large stock of noncore liabilities of the

\footnotetext{
For example, see Bernardini and Forni (2017).
} 
banking sector that are defined as consisting mostly of banks' borrowings from foreign banks makes a country more vulnerable to crisis. Kleimeier, Sander, and Heuchemer (2013) show financial crises could broaden and deepen the cross-border banking network using a gravity model, when the customers, living in crisis-affected countries, search for safe havens and reliable lenders abroad; however, when the crisis took place in safe havens, depositors could drive a major flight out of not only from the crisis country but also from their own economies fearing the crisis spillover. Hale, Kapan, and Minoiu (2016) also define measures of direct and indirect exposures to crises at the individual bank level and find that the profitability and loan supply of banks with larger exposures decline during crises. Morrison et al. (2016) identify bank credit default swap returns attributable to counterparty losses through the network of credit default swap transactions between banks and show that information about counterparty losses is transmitted to a bank's own credit default swap spread.

While most studies so far do not stress economic proximity in transmitting shocks through bank networks, there are a few exceptions that have paid attention to the regional linkages of banks within the global bank network. Minoiu and Reyes (2013) investigate the time-varying structural properties of the cross-border bank lending network. They identify the collapse of international lending by foreign banks as a key channel of transmission of financial crises when the shortages of interbank and cross-border liquidity also lead to a general weakening in the balance sheets of both foreign affiliates and domestic banks. They note this pattern of collapse in international bank lending networks is more severe at the regional level, as during crises in Latin America and East Asia, perhaps due to regional network effects. However, the regional banking network may also provide some buffer against the spillover effects of global crisis. Cerutti, Hale, and Minoiu (2015) examine the composition and drivers of cross-border bank lending and find that during the global financial crisis higher information asymmetries between the lender and borrower countries reduced cross-border loan exposures due to the need for loan screening and monitoring rises. They further show that economic proximity, that is, less information asymmetry, becomes more relevant for cross-border bank lending during crisis and leads to relatively stronger loan linkages. They also emphasize that their study is related to previous studies on the deleveraging that took place after the collapse of Lehman Brothers. For example, De Haas and Van Horen (2013) show that, during the crisis, banks continued to lend more to geographically close countries; where they have more lending experience, where they have more connections in a network of domestic colenders; and where they have more local presence.

This paper quantitatively assesses the effect of banking networks (more precisely, EMEs' bank exposures to advanced economies' banks) on cross-border credit flows during the global financial crisis, using Bank for International Settlements (BIS) international banking statistics. During the global financial crisis, cross-border bank lending slowed sharply due to heightened global uncertainty, and the impact of international bank retrenchment was considerable for EMEs. Park and Shin (2017) investigate whether an emerging economy with direct and indirect exposure to crisis countries experiences more bank capital outflows than those without such exposures. This paper examines whether an economy can be more susceptible to bank capital outflows regardless of its own bank exposures if other economies in the same region are heavily exposed to crisis countries. We use the BIS country-level bilateral bank claims data: (i) consolidated banking statistics (CBS) and (ii) locational banking statistics (LBS). We find evidence, particularly when we use the LBS, that emerging economies tend to experience more banking outflows regardless of their differences in fundamentals when other economies in the same region are exposed to the crisis-affected countries through their banking networks.

Another interesting hypothesis: if the lender were from the same region as the borrower, would it behave differently during crisis? Given that the same region lender may have more information than 
lenders from different regions, it is possible that the lender from the same region as the borrower behaves differently than lenders from other regions. Using the BIS statistics, we find that after controlling borrowers' exposures to crises countries, as well as their economic fundamentals, the same region lenders tend to reduce their exposures to the emerging market borrowers less during crisis. This finding is consistent with De Haas and Van Horen (2013) and Cerutti, Hale, and Minoiu (2015), which emphasize the role of regional banking networks in mitigating crisis propagation if a shock originates outside the region.

In the remainder of the paper, the next section explains the data used in the empirical analyses and recent trends in regional and global lending networks. Section III discusses the main empirical findings and section IV concludes.

\section{BILATERAL BANK CLAIMS DATA AND THEIR REGIONAL DECOMPOSITION}

We collect cross-border positions of banks from the CBS and LBS of the BIS. The CBS include the claims of reporting banks' foreign affiliates but exclude intragroup positions, similar to the consolidation approach followed by financial regulatory supervisors. ${ }^{2}$ Both sets of statistics report the claims (outstanding loans and holdings of securities) at a country rather than individual bank level, and are therefore suited for macro analysis of economic and financial stability issues. While the LBS provide information on the currency composition of resident banks' balance sheets, the CBS offer information about banking systems' risk exposures, in particular at the country level.

The first database, the CBS, reports claims at an aggregate level compiled by immediate counterparty and by ultimate risk bases. ${ }^{3}$ The CBS on the immediate counterparty basis report claims of banks headquartered in a reporting country for the other countries where their immediate counterparty exposure or risk lies. Foreign claims on an immediate counterparty basis are decomposed into (i) international claims and (ii) local positions in local currency. The international claims include both cross-border claims of a bank headquartered in the reporting country and local claims of its foreign affiliates in foreign currencies. International claims are disaggregated again in two different dimensions:

(i) by remaining maturities: (a) up to and including 1 year, (b) over 1 year and up to 2 years, and (c) over 2 years;

(ii) by sectors of the counterparty country that are divided into: (a) banks, (b) nonbank financial sector, (c) other private sector, and (d) official sector.

Local positions in local currency, the second type of foreign claims on immediate counterparty basis, refer to credits provided in local currency by foreign affiliates of the banks headquartered in the reporting country.

The CBS on the ultimate risk basis report the claims based on the country where the ultimate risk or obligor resides, after accounting for risk transfers, for example, using credit-risk mitigants such as collateral, guarantees, and credit protection. In other words, if claims are guaranteed, the CBS on the ultimate risk basis report the transfer of credit risk from the immediate counterparty to the country of ultimate risk (where the guarantor of a claim resides). On the ultimate risk basis, foreign claims are also disaggregated in two different approaches: (i) by the type of position, which are (a) cross-border

2 Detailed explanations of the BIS consolidated banking statistics can be found in BIS (2016).

3 See the explanation in BIS (2016) for the difference between the immediate country and ultimate risk bases we follow. 
claims and (b) local claims; and (ii) by the same four sectors the international claims by immediate counterparty are divided into (as indicated in the previous paragraph). The main difference of disaggregation between immediate counterparty and ultimate risk bases is that, for the former, local claims denominated in local currencies and international claims are not reported separately, no maturity breakdown is available, and foreign claims, not international claims, are disaggregated into four sectors. ${ }^{4}$

The second database, the LBS, reports the outstanding claims of banks that include intragroup positions between offices of the same banking group if they are in different countries. ${ }^{5}$ Hence the claims reported in the LBS include international transactions of a bank even with its own affiliates if they are located outside the reporting country. Therefore, the main difference between the CBS and the LBS is that the organization principle underlying the reporting requirement of the LBS is the location of the banking office. Another difference is that there are no claims reported on the ultimate risk basis in the LBS and all the statistics are based on the immediate counterparty basis.

In the LBS, banks' total international claims are decomposed into two different approaches:

(i) by category: (a) loans, (b) debt securities and (c) other assets that include equity shares, participations, derivative instruments, and working capital supplied by head offices to their branches abroad; and

(ii) by sector of the counterparty country and divided into (a) banks and (b) nonbanks.

In fact, claims in the LBS are disaggregated into total claims and claims on nonbanks, and hence claims on banks are calculated by subtracting the latter from the former. In addition, loans are disaggregated by banking and nonbanking sectors.

There are 28 reporting countries and 202 counterparty countries in the CBS, while the same numbers are 29 and 220, respectively, for the LBS. ${ }^{6}$ While the number of the BIS reporting countries is limited, the sum of all claims of these reporting countries against a counterparty country is comparable to the sum of all liabilities held by the counterparty country, as the BIS reporting countries cover most countries active in international bank loans.

In Figure 1, we illustrate the decomposition of total bank claims of reporting economies by five regions: East Asia, North America, Western Europe, Central and South America, and Oceania. Figure 1 a, by using the CBS, compares regional decomposition from the perspective of counterparty EMEs in East Asia. Regional shares of EMEs in East Asia are calculated by summing up claims of reporting economies located in each region against all EMEs in East Asia divided by total claims of reporting economies in all regions against all EMEs in East Asia. We calculate regional decompositions in Central and South America in a similar way. Appendix Table A1.1 lists reporting economies and EMEs of counterparty countries by region.

4 This difference is because the breakdown by booking office location for claims on an immediate-borrower basis differs from the breakdown on an ultimate risk basis. See BIS (2015) and Avdjiev, McGuire, and Wooldridge (2015) for more details.

5 See BIS $(2012,2013)$ for a detailed description of the nature of the locational banking statistics, which this paper mostly follows.

6 The CBS and LBS reporting economies are listed in the Appendix Table A1.1. In the CBS, we exclude Hong Kong, China; Luxembourg; and Norway as they do not report bilateral positions and in the LBS, we also exclude Bahamas, Bahrain, Bermuda, Cayman Islands, Curacao, Cyprus, Guernsey, India, Indonesia, Isle of Man, Italy, Jersey, Malaysia, Norway, Panama, the People's Republic of China, Portugal, the Russian Federation, Singapore, and Turkey, as they are either too small or they do not report bilateral positions. 
Figure 1a shows that, based on the CBS, the regional share of East Asia was highest at over 0.50 in the early 1990s. However, it decreased, even to below 0.10, in the mid-2000s and recently bounced slightly, back to over 0.20. In contrast, the share of Western Europe increased very rapidly and was over 0.70 in the mid-2000s. Still it is the largest, at over 0.50. The next highest share is taken by North America.

\section{Figure 1: Regional Shares of Total Claims in East Asia}

(a) Consolidated banking statistics on immediate counterparty basis

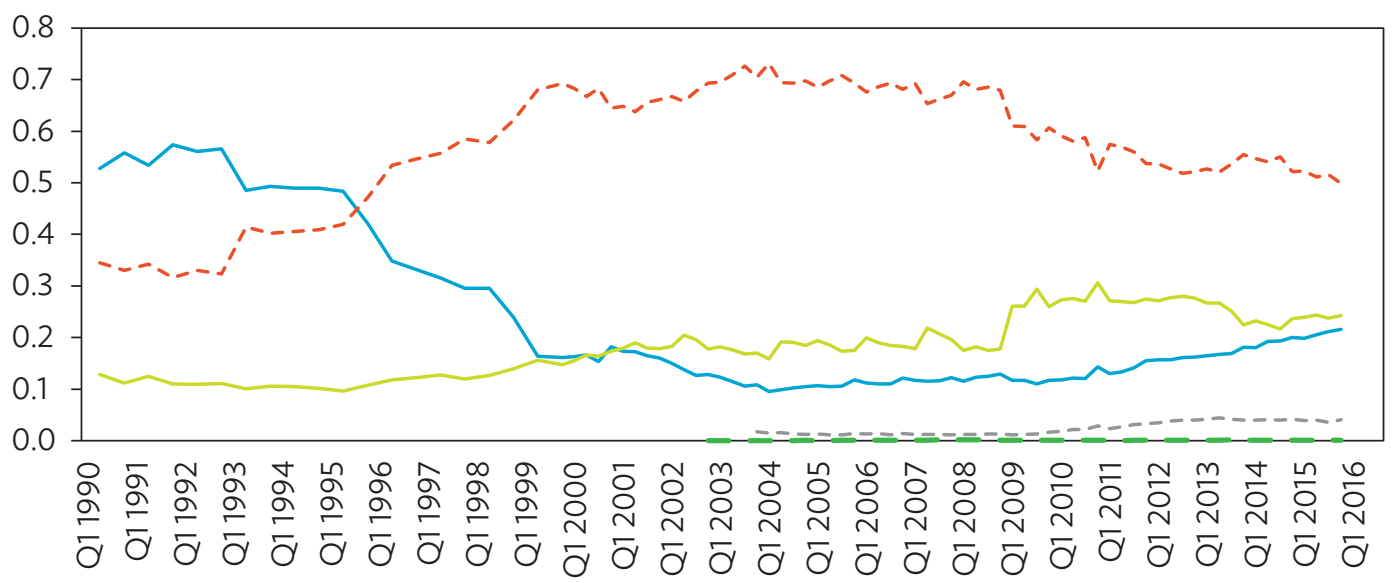

(b) Locational banking statistics cross-border total claims

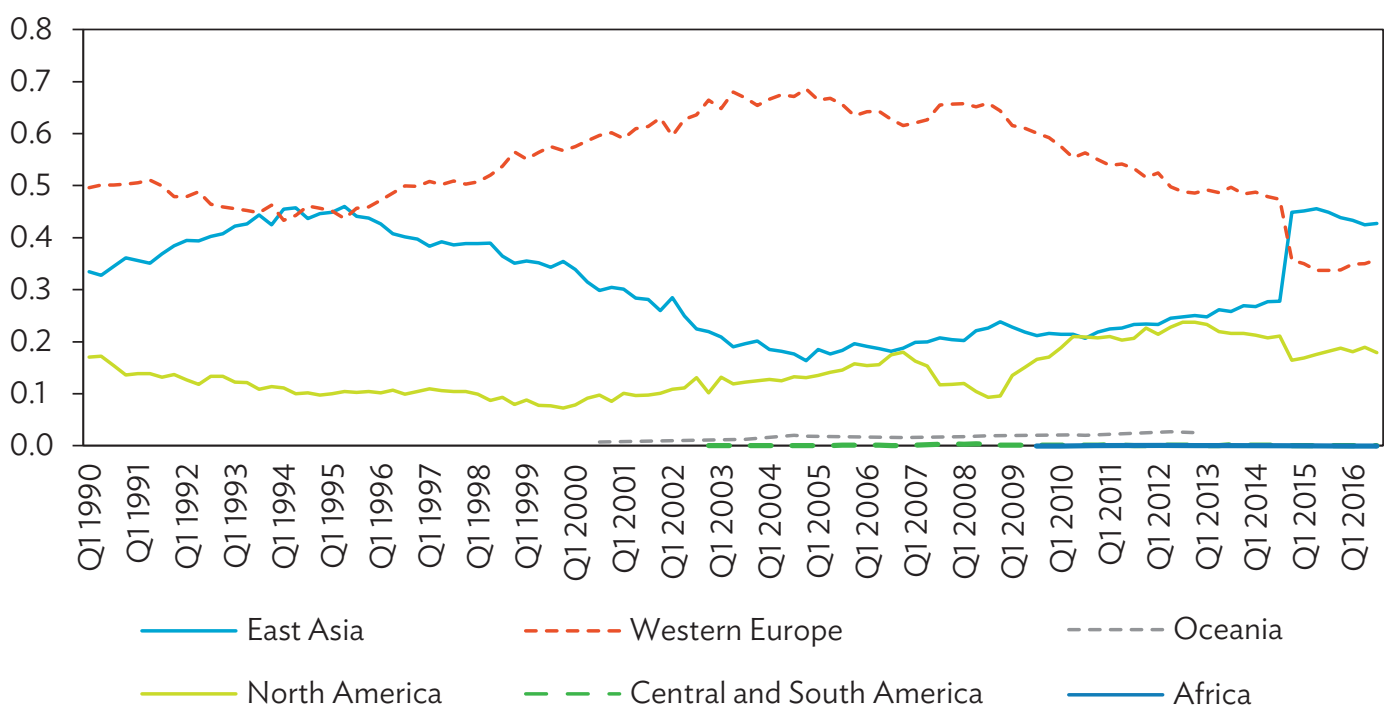

Notes: Share of the region is calculated by summing up claims of reporting economies in each region against all emerging market economies (EMEs) in East Asia divided by total claims of reporting economies in all regions against all EMEs in East Asia. The list of reporting economies in each region is in Appendix Table A1.1.

Source: Authors' calculation based on the Bank for International Settlement's locational banking statistics. 
Figure 2: Regional Shares of Total Claims in Central and South America

(a) Consolidated banking statistics on immediate counterparty basis

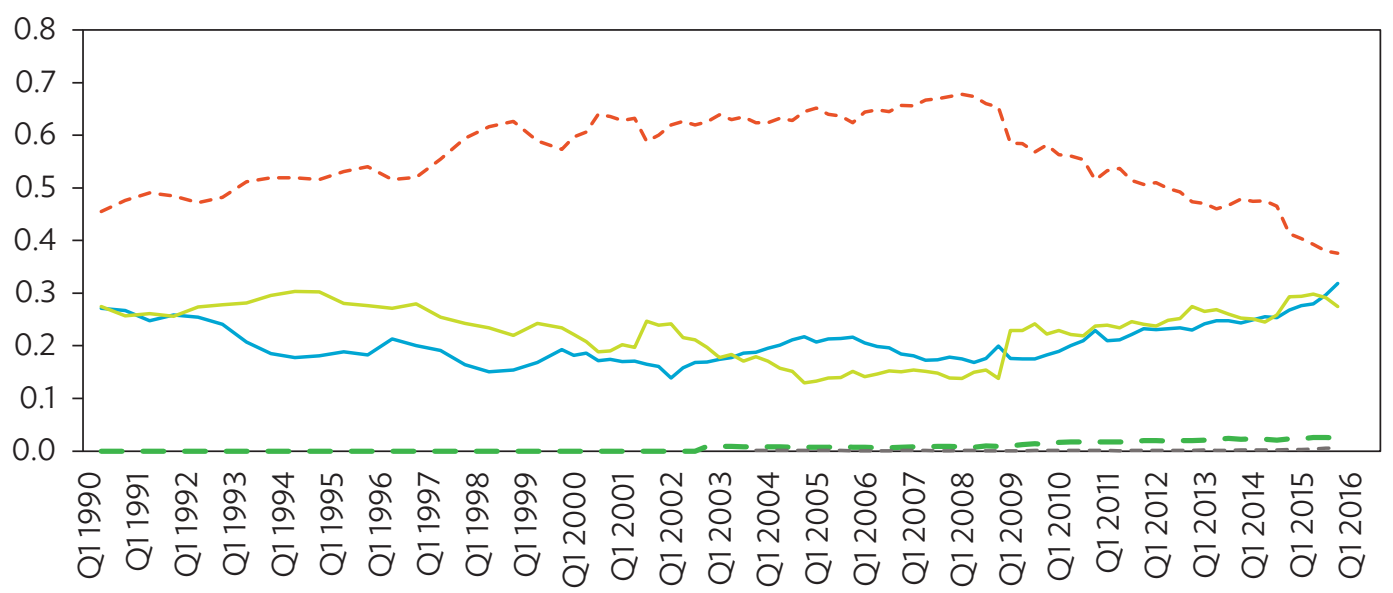

(b) Locational banking statistics cross-border total claims

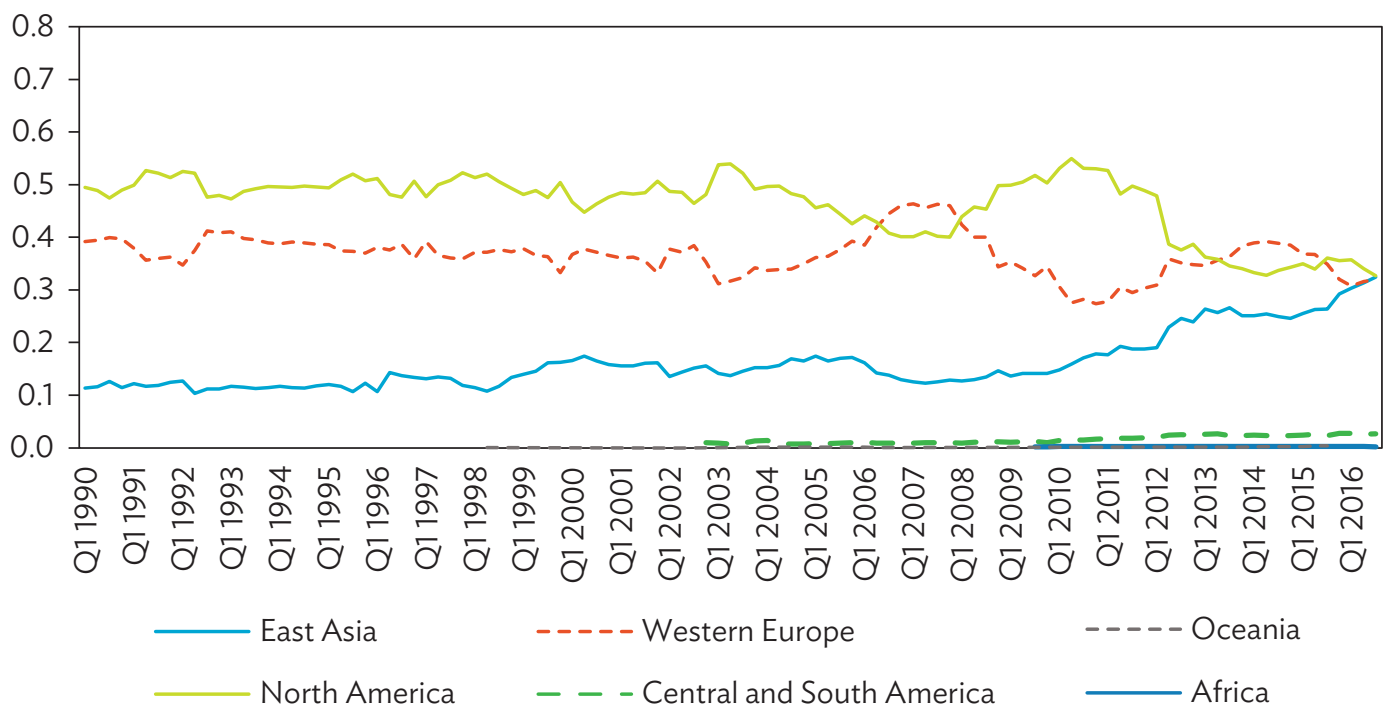

Notes: Share of the region is calculated by summing up claims of reporting economies located in each region against all emerging market economies (EMEs) in Central and South America divided by total claims of reporting economies in all regions against all EMEs in Central and South America. The list of reporting economies in each region is in Appendix Table A1.1.

Source: Authors' calculation based on the Bank for International Settlement's consolidated banking statistics. 
Figure 3: Regional Shares of Total Claims for Individual Emerging Market Economies, East Asia

(a) Consolidated banking statistics on immediate counterparty basis
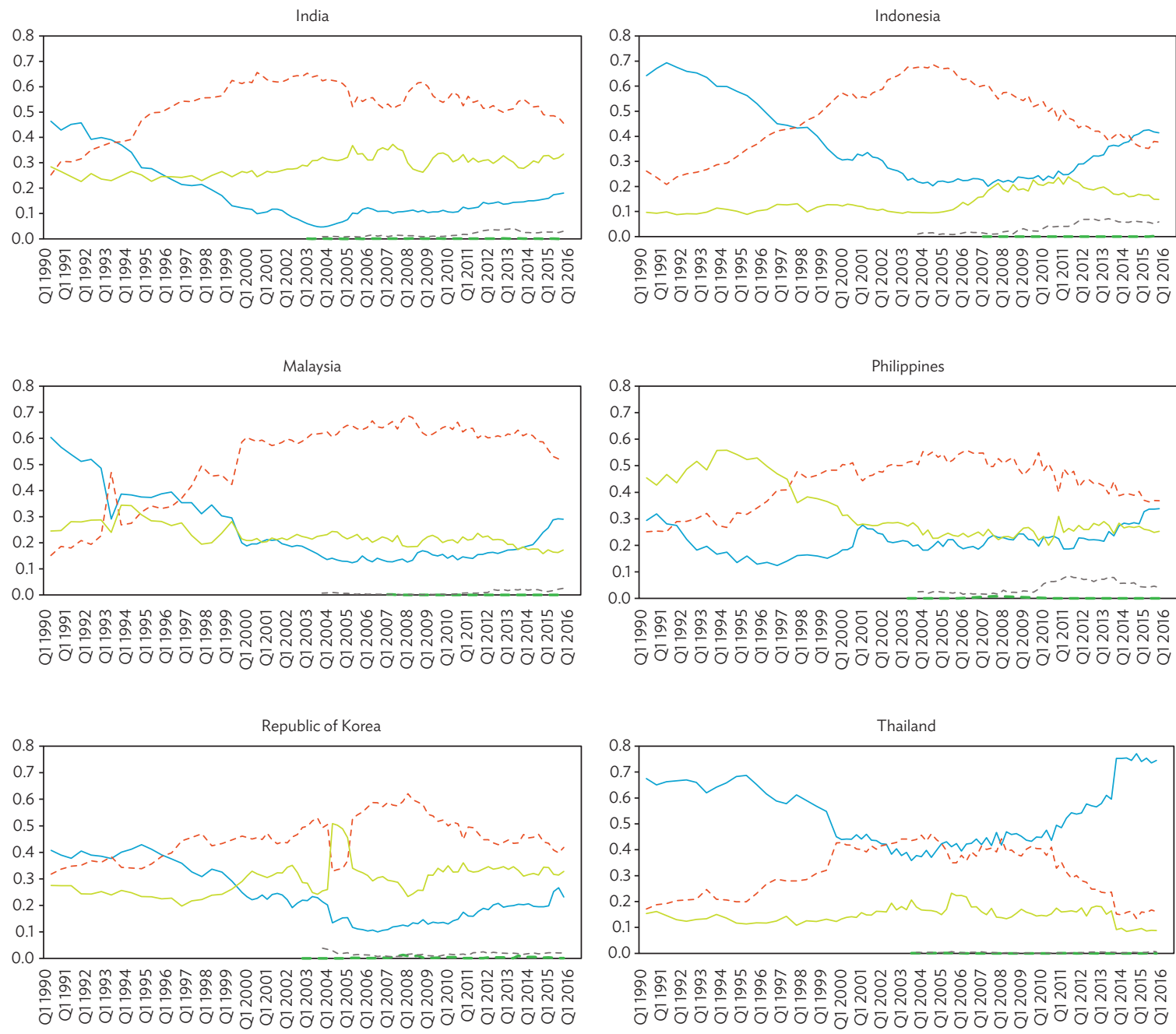

continued on next page 
Figure 3 continued

\section{(b) Locational bank statistics cross-border total claims}
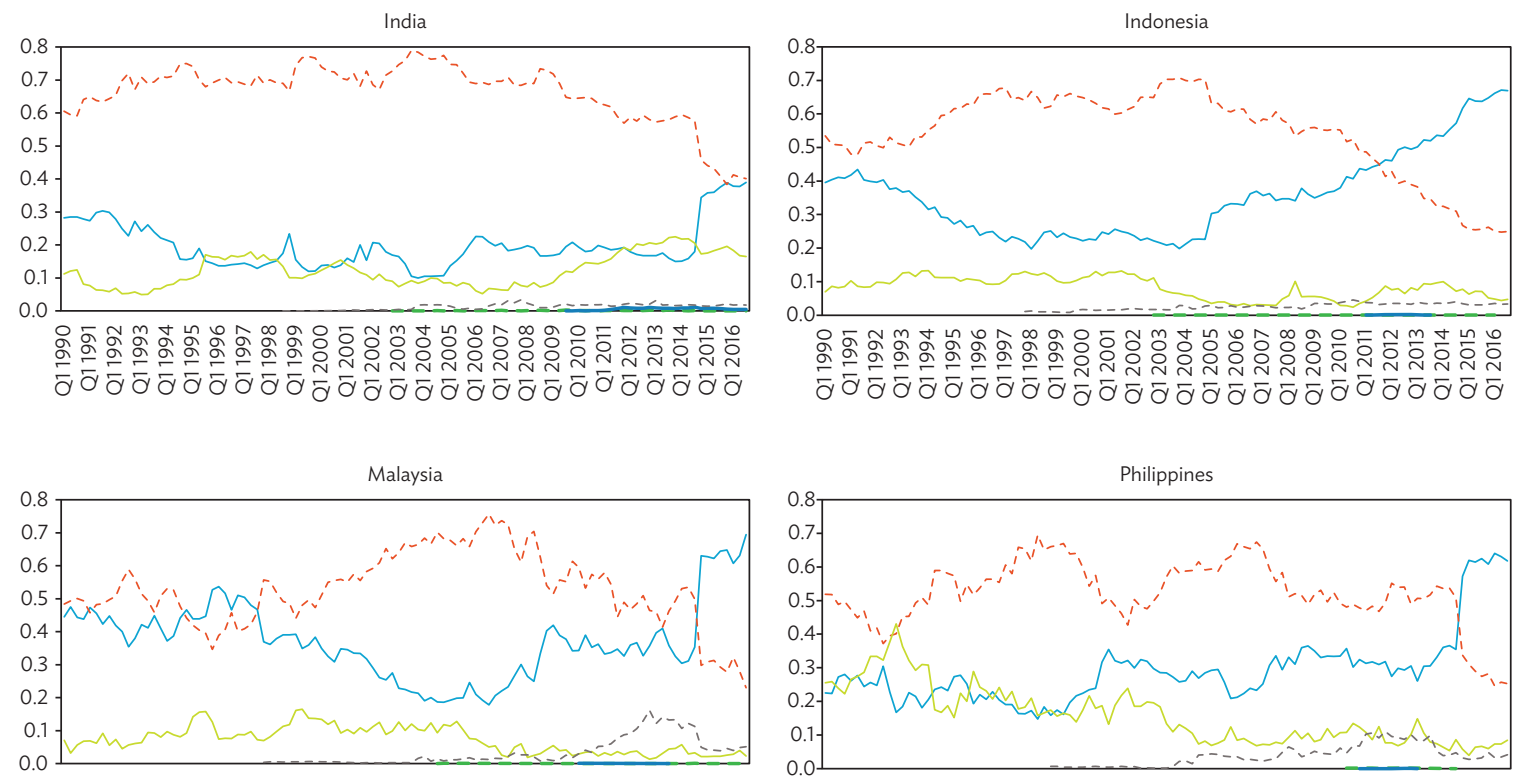

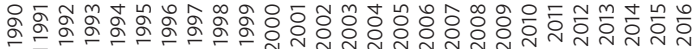

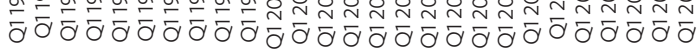
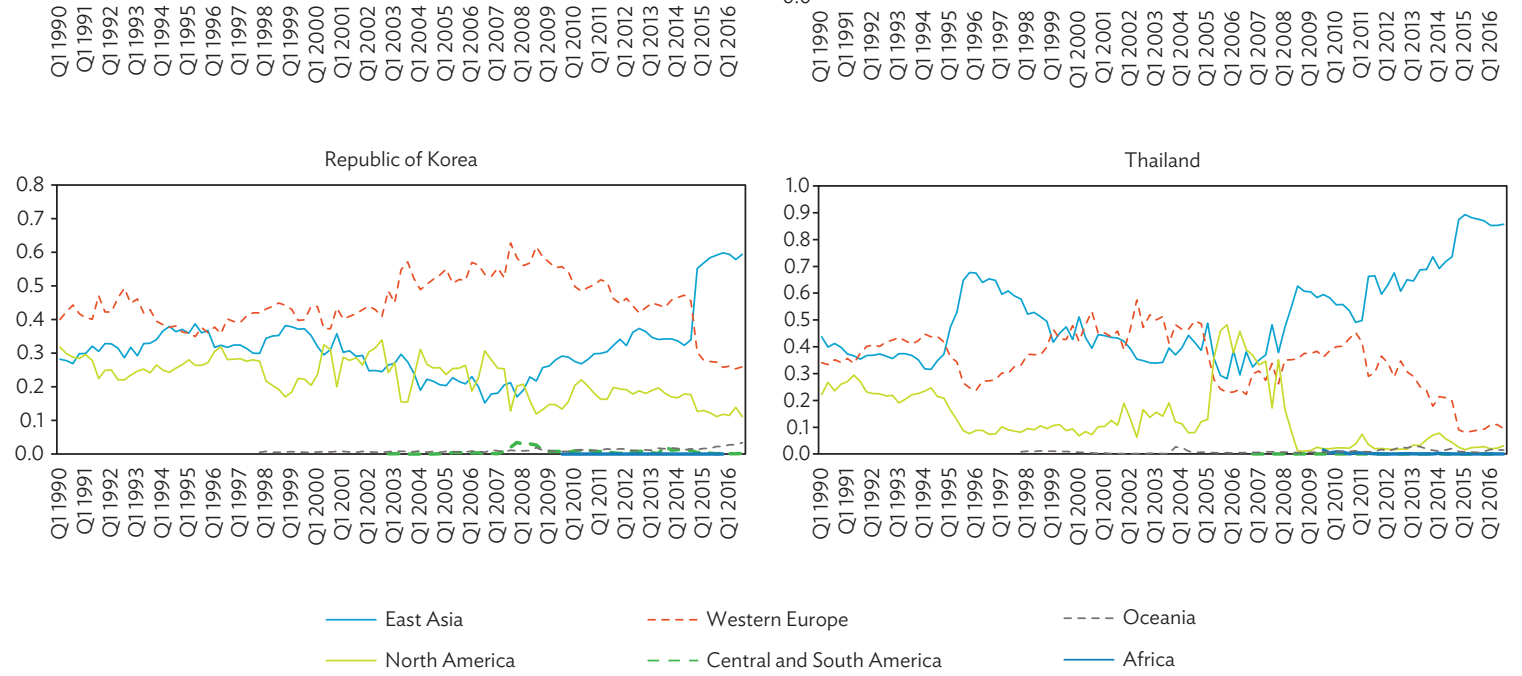

Notes: Share of the region is calculated by summing up claims of reporting economies located in each region against each individual country, divided by total claims of reporting economies in all regions against it. The list of reporting economies in each region is in Appendix Table A1.1.

Source: Authors' calculation based on the Bank for International Settlement's consolidated banking statistics. 
In Figure 1b, shares based on the LBS exhibit a generally similar pattern, except that the share of East Asia suddenly jumped in 2015 and became the largest. This is mostly because Hong Kong, China started to be included as a reporting economy in the LBS in 2015 and had a large share of claims in East Asia.

Figures $2 \mathrm{a}$ and $2 \mathrm{~b}$ present regional shares of claims in Central and South America. Figure $2 \mathrm{a}$ shows that, based on the CBS, the regional share of Western Europe has been largest in Central and South America. Recently, however, shares of North America and East Asia have gained and are now very close to that of Western Europe. Shares of other regions are minimal and, hence, claims in Central and South America are now almost equally divided into three regions: Western Europe, North America, and East Asia.

In Figure 2b, shares based on the LBS exhibit a somewhat different feature. The share of North America is generally highest, followed by Western Europe. However, the share of East Asia has recently been increasing very rapidly and again in recent years, the claims are almost equally divided into the same three regions.

Figure 3 illustrates regional shares in individual East Asian countries based on the CBS (Figure 3a) and the LBS (Figure 3b), respectively.

\section{REGIONAL CONTAGION OF VULNERABILITIES}

In this section, we utilize the measures of direct and indirect bank liability exposures of emerging economies, developed by Park and Shin (2017), to investigate the contagion effect of a country's bank liability exposures to other countries in the same region. ${ }^{7}$ Building on Park and Shin (2017), which examined the effect of emerging economies' bank liability exposure to advanced economies, we test whether or not a country faces more banking outflows if its neighboring countries have banking exposures to the crisis-affected countries.

First, we follow Park and Shin (2017) to define direct exposure, denoted by $D E_{i, t}$, of an emerging economy $i$ at time $t$ to banks in crisis countries as the sum of shares of total claims against country $i$, held by all countries that experience crises:

$$
D E_{i, t}=\sum_{j \in C_{t}} \operatorname{share}_{i j, t}^{t}, \text { share }_{i j, t}^{t}=\frac{t c_{i j t}}{\sum_{k=1}^{N} t c_{i k t}}
$$

where $N$ is the number of reporting countries, $t c_{i k t}$ stands for the total claims held by reporting country $k$ on counterparty country $i$ at time $t$ and, hence, $\operatorname{share}_{i j, t}^{t}$ is the share of total claims held by reporting country $j$ on country $i$ at time $t$. Since the set, $C_{t}$, includes all reporting countries that experience crises at time $t$, the direct exposure captures the share of foreign claims held by all reporting countries that experience crisis. They also define an indirect exposure of foreign claims of an emerging economy $i$ at time $t, I D E_{i, t}$, as follows:

$$
I D E_{i, t}=\sum_{j} \operatorname{share}_{i j, t}^{t} \cdot D E_{j, t}
$$

7 Park and Shin (2017) constructed measures of direct and indirect exposures through the global bank network following the approach developed by Hale, Kapan, and Minoiu (2016). 
The direct exposure captures the extent to which a country is exposed to the crisis-affected countries through its borrowings from them. The idea is that if the crisis-affected countries facing liquidity and risk constraints withdraw funds or reverse their lending, the country that borrowed from them can also be vulnerable. While the direct exposure measures the share of claims held by the crisisaffected countries only, the indirect exposure of foreign claims is the weighted average of direct exposures faced by all reporting countries. Hence, the indirect exposure account for the spillover effects of even noncrisis-reporting countries, which can draw down their lending to emerging economies due to their direct exposures to crisis-affected countries.

We measure three direct and indirect exposures of total claims based on the CBS's total foreign claims on immediate borrower and ultimate risk bases and the LBS's total cross-border claims. Since bilateral claims are available in disaggregated sector and maturity levels, we can calculate direct and indirect exposures of specific sectors and/or different maturities, as in Park and Shin (2017). For the CBS, the disaggregated data at the sectoral level are available on an ultimate risk basis only. In the LBS, bilateral claims at the sectoral level are available for total cross-border claims and cross-border loans. Utilizing these disaggregated data, we define direct and indirect exposures of the banking sector, $D E_{i, t}^{b}$ and $I D E_{i, t}^{b}$, based on claims on the banking sector in the counterparty country:

$$
\begin{gathered}
D E_{i, t}^{b}=\sum_{j \in C_{t}} \operatorname{share}_{i j, t}^{b}, \operatorname{share}_{i j, t}^{b}=\frac{b c_{i j t}}{\sum_{k=1}^{N} b c_{i k t}} \\
I D E_{i, t}^{b}=\sum_{j} \operatorname{share}_{i j, t}^{b} \cdot D E_{j, t}^{b}
\end{gathered}
$$

where $\operatorname{share}_{i j, t}^{b}$ is the share of foreign claims held by country $j$ on the banking sector in country $i$ at time t. As emphasized by Park and Shin (2017), the measures of bank exposures based on the claims against the banking sector are critical since the liabilities of the banking sector play a crucial role in transmitting shocks. ${ }^{8}$

Park and Shin (2017) also define direct and indirect exposures of short-term maturities, $D E_{i, t}^{S}$ and $I D E_{i, t}^{S}$, using data on claims of maturities with less than 1 year on the counterparty country as follows:

$$
\begin{gathered}
D E_{i, t}^{S}=\sum_{j \in C_{t}} \operatorname{share}_{i j, t}^{S}, \operatorname{share}_{i j, t}^{S}=\frac{s c_{i j t}}{\sum_{k=1}^{N} s c_{i k t}} \\
I D E_{i, t}^{S}=\sum_{j} \operatorname{share}_{i j, t}^{S} \cdot D E_{j, t}^{S}
\end{gathered}
$$

where $\operatorname{share}_{i j, t}^{S}$ is the share of short-term claims held by country $j$ on country $i$ at time $t$. Since longterm claims are not easily withdrawn even by troubled banks in crisis-affected countries, EMEs are expected to be more vulnerable to short-term borrowing exposures.

Park and Shin (2017) show that countries that are more exposed to banks in crisis-affected countries, directly and/or indirectly, suffered more banking outflows during the global financial crisis. In this paper, we explore the contagion effects of such banking outflows from EMEs in the same region. For example, if a country has neighbors that are more exposed to banks in crisis-affected countries,

8 For example, Hahm, Shin, and Shin (2013) define noncore liabilities of the banking sector as consisting mostly of banks' borrowings from foreign banks and show that a large stock of noncore liabilities makes a country more vulnerable to a crisis. 
that country may suffer more banking outflows, irrespective of its own economic conditions and crisis exposures.

To do this, we first measure the average bank exposure at the regional level, excluding the country concerned, and examine if this regional exposure has additional explanatory power for the country's banking outflows.

Following Park and Shin (2017), we measure the rate of total banking outflows from country $i$

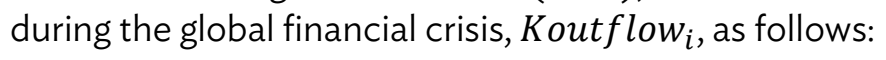

$$
\text { Koutflow }_{i}=\frac{T F C_{i}^{\max }-T F C_{i}^{\min }}{T F C_{i}^{\max }}
$$

where $T F C_{i}^{\max }$ and $T F C_{i}^{\text {min }}$ are the maximum and the minimum levels of total claims of all reporting countries on country $i$ during the period from the first quarter (Q1) of 2007 to Q3 2008 and the period after Q3 2008, respectively. That is, we are assuming that the difference between the maximum level before and the minimum level after the crisis represents the volume of capital outflows from country $i$. We also calculate the rate of bilateral bank-led capital outflows from country $i$ to reporting country $j$ during the global financial crisis, Koutflow Ka $_{i j}$ as follows:

$$
\operatorname{Koutflow}_{i j}=\frac{T F C_{i j}^{\max }-T F C_{i j}^{\min }}{T F C_{i j}^{\max }}
$$

where $T F C_{i j}^{\max }$ and $T F C_{i j}^{\min }$ are the maximum and the minimum levels, respectively, of total claims of reporting country $j$ on country $i$ during the period from Q1 2007 to Q3 2008 and the period after Q3 2008. Again, we assume that the difference between the maximum level before and the minimum level after the crisis represents the volume of banking outflows from country $i$ to $j$. We use both CBS's total foreign claims on immediate counterparty basis and LBS's total cross-border claims in calculating banking outflows.

To test if there is contagion in banking outflows within the same geographic region, we estimate the following equation for aggregate banking outflows:

$$
\text { Koutflow }_{i}=\beta_{0}+\beta_{1} D E_{i, 2007}+\beta_{1}^{R} D E_{i, 2007}^{R}+\beta_{2} I D E_{i, 2007}+\beta_{2}^{R} I D E_{i, 2007}^{R}+\beta_{3} X_{i 2007}+\varepsilon_{i}
$$

where $D E_{i, 2007}^{R}$ and $I D E_{i, 2007}^{R}$ are regional averages of direct and indirect exposures, respectively, of foreign claims at time $t$ for an emerging economy $i$ that belongs to region $R$. In calculating regional averages, we exclude emerging economy $i$ from the region, i.e., $D E_{i, 2007}$ and $I D E_{i, 2007}$ are its own exposures while $D E_{i, 2007}^{R}$ and $I D E_{i, 2007}^{R}$ are average exposures of the other countries in the same region. We also include other control variables, $X_{i 2007}$, that may prompt capital outflows. The main difference of equation (8) from the equation estimated in Park and Shin (2017) is that we now include regional averages of direct and indirect exposures as explanatory variables. In this setup, the coefficients of regional averages indicate the extent to which each country is affected by the degree of regional exposures. For example, a country may fall victim to a crisis even if the country itself is not particularly exposed to the crisis-affected country, but it is in the same region as other countries that are exposed to the crisis-affected countries. Therefore, if the coefficients of regional exposures are statistically significant, it may suggest there is regional contagion in capital flows. 
We can also estimate the same regression as (8) but using the bilateral banking outflows Koutflow $_{i j}$ instead of Koutflow : $^{\prime}$

$$
\begin{gathered}
\text { Koutflow }_{i j}=\beta_{0}+\beta_{1} D E_{i, 2007}+\beta_{1}^{R} D E_{i, 2007}^{R}+\beta_{2} I D E_{i, 2007}+ \\
\beta_{2}^{R} I D E_{i, 2007}^{R}+\beta_{3} d^{R}+\beta_{4} X_{i 2007}+\varepsilon_{i}
\end{gathered}
$$

In equation (10), we also add a region dummy, $d^{R}$, which takes 1 if the reporting country $j$ belongs to the same region as an emerging market economy $i$. The coefficient of the dummy represents the extent to which the reporting country treats the emerging market economy in the same region differently vis-à-vis emerging economies in other regions.

We will also estimate, for the aggregate capital outflows, the following two equations:

$$
\begin{aligned}
& \text { Koutflow }_{i}=\beta_{0}+\beta_{1} D E_{i, 2007}^{b}+\beta_{1}^{R} D E_{i, 2007}^{b R}+\beta_{2} I D E_{i, 2007}^{b}+\beta_{2}^{R} I D E_{i, 2007}^{b R}+\beta_{3} X_{i 2007}+\varepsilon_{i} \\
& \text { Koutflow }_{i}=\beta_{0}+\beta_{1} D E_{i, 2007}^{S}+\beta_{1}^{R} D E_{i, 2007}^{s R}+\beta_{2} I D E_{i, 2007}^{S}+\beta_{2}^{R} I D E_{i, 2007}^{s R}+\beta_{3} X_{i 2007}+\varepsilon_{i}
\end{aligned}
$$

where $D E_{i, 2007}^{b}$ and $I D E_{i, 2007}^{b}$ are direct and indirect exposures of the banking sector, respectively. $D E_{i, 2007}^{S}$ and $I D E_{i, 2007}^{S}$ are direct and indirect exposures, respectively, of short-term claims and $D E_{i, 2007}^{b R}, I D E_{i, 2007}^{b R}, D E_{i, 2007}^{S R}$, and $I D E_{i, 2007}^{S R}$ are the corresponding regional averages. Estimating equations (11) and (12) will present the importance of exposures of the banking sector and short-term claims and their regional contagion. Finally, we will also estimate the equations as (11) and (12) using

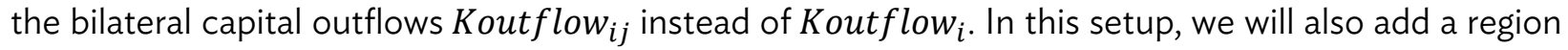
dummy, $d^{R}$, as an additional explanatory variable.

\section{EMPIRICAL FINDINGS}

For country $i$, we choose 65 EMEs from the set of counterparty countries in CBS and LBS. ${ }^{9}$ The list of EMEs is identical to that in Park and Shin (2017).

Table 1 summarizes the basic statistics of the variables used to estimate equations set up in the previous section. We measure two direct/indirect exposures of total claims based on the CBS on immediate counterparty and LBS total cross-border claims. We also present summary statistics on regional average for each direct and indirect exposure. Generally, direct and indirect exposures based on the LBS are lower than those based on the CBS, which indicates that there are considerable transactions between headquarters in reporting countries and their affiliates in EMEs. Moreover, there are more bilateral observations based on the LBS than based on the CBS.

9 Appendix Table A1.1 lists the emerging economies considered in the paper. The list of emerging economies is from Park, Ramayandi, and Shin (2016) that follows Eichengreen and Gupta (2015) and Lim, Mohapatra, and Stocker (2014). When reporting estimation results, we drop countries whose total claims at the maximum before the global financial crisis is less than $\$ 500$ million based on either the CBS or the LBS total foreign claims. These countries are Albania, Armenia, Cape Verde, Georgia, the Kyrgyz Republic, Lesotho, Macedonia, Moldova, Mongolia, Mozambique, Nicaragua, Suriname, Uganda. The results based on all EMEs are similar, with qualitative conclusions remained the same. These results will be available upon request. 
Table 1: Summary Statistics

\begin{tabular}{|c|c|c|c|c|}
\hline & Count & Mean & Min & Max \\
\hline Direct exposure of the entire sector on counterparty basis (CBS) & 49 & 0.95 & 0.53 & 1.00 \\
\hline Indirect exposure of the entire sector on counterparty basis (CBS) & 49 & 0.91 & 0.85 & 0.95 \\
\hline Regional direct exposure of the entire sector on counterparty basis (CBS) & 48 & 0.94 & 0.81 & 0.99 \\
\hline Regional indirect exposure of the entire sector on counterparty basis (CBS) & 48 & 0.91 & 0.89 & 0.92 \\
\hline Direct exposure of the entire sector (LBS) & 49 & 0.86 & 0.35 & 1.00 \\
\hline Indirect exposure of the entire sector (LBS) & 49 & 0.84 & 0.75 & 0.94 \\
\hline Regional direct exposure of the entire sector (LBS) & 48 & 0.88 & 0.70 & 0.98 \\
\hline Regional indirect exposure of the entire sector (LBS) & 48 & 0.84 & 0.80 & 0.90 \\
\hline Direct exposure of the banking sector (CBS) & 48 & 0.93 & 0.65 & 1.00 \\
\hline Indirect exposure of the banking sector (CBS) & 48 & 0.89 & 0.87 & 0.93 \\
\hline Regional direct exposure of the banking sector (CBS) & 48 & 0.89 & 0.39 & 0.99 \\
\hline Regional indirect exposure of the banking sector (CBS) & 48 & 0.89 & 0.88 & 0.90 \\
\hline Direct exposure of the banking sector (LBS) & 49 & 0.84 & 0.00 & 1.00 \\
\hline Indirect exposure of the banking sector (LBS) & 49 & 0.81 & 0.64 & 0.96 \\
\hline Regional direct exposure of the banking sector (LBS) & 48 & 0.89 & 0.71 & 0.98 \\
\hline Regional indirect exposure of the banking sector (LBS) & 48 & 0.80 & 0.70 & 0.89 \\
\hline Direct exposure of short-term debts (CBS) & 49 & 0.90 & 0.46 & 1.00 \\
\hline Indirect exposure of short-term debts (CBS) & 49 & 0.91 & 0.88 & 0.94 \\
\hline Regional direct exposure of short-term debts (CBS) & 48 & 0.89 & 0.74 & 0.98 \\
\hline Regional indirect exposure of short-term debts (CBS) & 48 & 0.90 & 0.89 & 0.93 \\
\hline Aggravation of current account balance & 49 & -2.60 & -19.10 & 14.50 \\
\hline Real appreciation & 44 & -0.08 & -0.22 & 0.11 \\
\hline Increase in domestic credit & 49 & 9.10 & -10.40 & 33.90 \\
\hline GDP growth & 49 & 6.70 & 0.40 & 11.10 \\
\hline $\mathrm{CPI}$ inflation rate & 47 & 6.80 & 0.50 & 18.70 \\
\hline Chinn-Ito Index, normalized in 2007 & 49 & 0.60 & 0.20 & 1.00 \\
\hline Standard \& Poor's Sovereign LCU Credit Rating in 2007 & 46 & 13.2 & 7.00 & 20 \\
\hline Total immediate foreign claims (CBS) & 568 & 4,459 & 0.00 & 149,207 \\
\hline Total cross-border foreign claims (LBS) & 818 & 1,611 & 1.00 & 68,189 \\
\hline Ultimate foreign claims on the banking sector (CBS) & 248 & 968 & 0.00 & 20,158 \\
\hline Cross-border foreign claims of the banking sector (LBS) & 708 & 788 & 0.00 & 26,993 \\
\hline Short-term international borrowings (CBS) & 294 & 1,105 & 0.00 & 26,254 \\
\hline
\end{tabular}

$\mathrm{CBS}=$ consolidated banking statistics, $\mathrm{CPI}=$ consumer price index, GDP = gross domestic product, $\mathrm{LBS}$ = locational banking statistics, $\mathrm{LCU}=$ local currency unit.

Notes: Bilateral claims are measured in millions of United States dollars. Originally some values of claims are reported to be negative because the Bank for International Settlements (BIS) overwrites the unallocated member with a calculated residual to ensure consistency. In the above summary statistics, however, we excluded the negative values. If the amounts of claims are recorded as negative values, then the exposure measures can exceed 1, as reported in the working paper version. Problem corrected by equating the negative value to zero. Source: Authors' calculations based on the BIS statistics. 
Table 2 reports regression results from estimating equation (9) using two exposure measures of total claims, the CBS on immediate counterparty basis (Table 2a) and the LBS (Table 2b)..$^{10}$ Exposure measures are calculated for Q4 2007, just before the global financial crisis. We employed additional control variables of country $i$ at time $t$, adopted in Eichengreen and Gupta (2015) and Park, Ramayandi, and Shin (2016), i.e., aggravation of current account balances, real exchange rate appreciation before the global financial crisis, increase in domestic credit-to-gross domestic product (GDP) ratio, inflation rate, and real GDP growth rate. " Following Park and Shin (2017), we also add the Chinn-Ito index as a proxy for capital market liberalization and sovereign credit rating to these control variables, as they are commonly regarded as important factors for capital flows to EMEs.

Table $2 \mathrm{a}$ shows that the estimated coefficients of direct exposure measures are highly significant at least at the $5 \%$ level in every column, indicating that the direct exposure is a major factor for banking outflows. When we add the indirect exposure in columns (5)-(8), it is also positive and statistically significant either at the $5 \%$ or $10 \%$ level in columns (5) and (6), suggesting that indirect exposure is also responsible for banking outflow. If we add regional direct exposures in columns (2)(4) and both regional direct and indirect measures in (5)-(8), the regional direct exposure is always positive, but statistically significant only in column (2). In contrast, the regional indirect measure is not statistically significant. Other control variables are also not statistically significant.

But Table $2 b$, which is based on the LBS, shows somewhat different results. The country's own direct exposure and regional direct exposure are positive and statistically significant at the $5 \%$ level in column (1) and in column (2), respectively. In contrast, the regional indirect exposure is positive and statistically significant at the $1 \%$ level in column (5) and if we also add the regional indirect exposure in columns (6)-(8), it becomes insignificant and the regional indirect exposure is statistically significant at the $1 \%$ or $10 \%$ level in columns (6) and (7), indicating strong contagion effects at the regional level. Among other control variables, less appreciation in real exchange rates has consistently negative influence on the size of banking flows with high statistical significance.

Tables $2 c$ and $2 d$ report the regression results from estimating equation (10) that utilizes bilateral banking outflows based on the CBS and the LBS, respectively. In Table 2c, the evidence is somewhat weaker, but the direct exposure is still a major factor in explaining capital outflows. However, we do not see evidence of contagion effects. Interestingly, the coefficient of the same region dummy is negative and statistically significant at the $1 \%$ level in all columns, indicating that withdrawals of claims from emerging economies are less if the reporting country is in the same region. Among other control variables, an increase in domestic credit and capital market liberalization has positive impact on capital outflows, with statistical significance.

In contrast, Table $2 \mathrm{~d}$, which is based on the LBS, again shows evidence of contagion effects at the regional level. While the coefficients of the country's own direct and indirect exposures are not statistically significant, the regional direct exposure is statistically significant at the $1 \%$ or $5 \%$ level in columns (2) and (4), and the regional indirect exposure is statistically significant at the $5 \%$ level in column (4). However, while the coefficient of the same region dummy is always negative, the statistical significance is much weaker.

10 We can also use total claims and exposure measures based on the CBS on ultimate risk basis, but the qualitative results do not change.

11 See Eichengreen and Gupta (2015) and Park, Ramayandi, and Shin (2016) for the motivation of including these as explanatory variables. 
Table 2: Contagion Effects in Capital Outflows in the Region

(a) Total foreign claims of the consolidated banking statistics on immediate counterparty basis (aggregate)

\begin{tabular}{|c|c|c|c|c|c|c|c|c|}
\hline Variables & $\begin{array}{c}(1) \\
\text { Outflow }\end{array}$ & $\begin{array}{c}\text { (2) } \\
\text { Outflow }\end{array}$ & $\begin{array}{c}\text { (3) } \\
\text { Outflow }\end{array}$ & $\begin{array}{c}(4) \\
\text { Outflow }\end{array}$ & $\begin{array}{c}\text { (5) } \\
\text { Outflow }\end{array}$ & $\begin{array}{c}(6) \\
\text { Outflow }\end{array}$ & $\begin{array}{c}(7) \\
\text { Outflow }\end{array}$ & $\begin{array}{l}(8) \\
\text { Outflow }\end{array}$ \\
\hline $\begin{array}{l}\text { Direct exposure of the } \\
\text { entire sector on immediate } \\
\text { counterparty basis (CBS) } \\
\text { in } 2007\end{array}$ & $\begin{array}{l}1.316^{* * *} \\
{[0.360]}\end{array}$ & $\begin{array}{l}0.842^{* *} \\
{[0.376]}\end{array}$ & $\begin{array}{l}0.921^{* *} \\
{[0.402]}\end{array}$ & $\begin{array}{l}0.909^{* *} \\
{[0.395]}\end{array}$ & $\begin{array}{l}1.436^{* * *} \\
{[0.330]}\end{array}$ & $\begin{array}{r}1.107^{* *} \\
{[0.429]}\end{array}$ & $\begin{array}{l}0.897^{* *} \\
{[0.426]}\end{array}$ & $\begin{array}{l}0.933^{* *} \\
{[0.411]}\end{array}$ \\
\hline $\begin{array}{l}\text { Regional direct exposure of } \\
\text { the entire sector on } \\
\text { immediate counterparty } \\
\text { basis (CBS) in } 2007\end{array}$ & & $\begin{array}{l}1.206^{* *} \\
{[0.544]}\end{array}$ & $\begin{array}{r}0.590 \\
{[0.559]}\end{array}$ & $\begin{array}{r}1.009 \\
{[0.744]}\end{array}$ & & $\begin{array}{r}0.765 \\
{[0.647]}\end{array}$ & $\begin{array}{r}0.587 \\
{[0.736]}\end{array}$ & $\begin{array}{r}0.958 \\
{[0.874]}\end{array}$ \\
\hline $\begin{array}{l}\text { Indirect exposure of the } \\
\text { entire sector on immediate } \\
\text { counterparty basis (CBS) } \\
\text { in } 2007\end{array}$ & & & & & $\begin{array}{l}3.501^{* *} \\
{[1.662]}\end{array}$ & $\begin{array}{l}3.007^{*} \\
{[1.703]}\end{array}$ & $\begin{array}{r}-0.250 \\
{[2.040]}\end{array}$ & $\begin{array}{r}0.440 \\
{[2.004]}\end{array}$ \\
\hline $\begin{array}{l}\text { Regional indirect exposure } \\
\text { of the entire sector on } \\
\text { immediate counterparty } \\
\text { basis (CBS) in } 2007\end{array}$ & & & & & & $\begin{array}{r}0.507 \\
{[3.873]}\end{array}$ & $\begin{array}{r}0.347 \\
{[4.742]}\end{array}$ & $\begin{array}{r}0.396 \\
{[4.947]}\end{array}$ \\
\hline $\begin{array}{l}\text { Aggravation of current } \\
\text { account balance } \\
\text { 2004-2007 }\end{array}$ & & & $\begin{array}{r}-0.005 \\
{[0.008]}\end{array}$ & $\begin{array}{r}-0.006 \\
{[0.007]}\end{array}$ & & & $\begin{array}{r}-0.005 \\
{[0.009]}\end{array}$ & $\begin{array}{r}-0.006 \\
{[0.008]}\end{array}$ \\
\hline $\begin{array}{l}\text { Average annual percentage } \\
\text { change in the real exchange } \\
\text { rate, 2005-2007 }\end{array}$ & & & $\begin{array}{l}-0.365 \\
{[0.621]}\end{array}$ & $\begin{array}{l}-0.348 \\
{[0.587]}\end{array}$ & & & $\begin{array}{r}-0.353 \\
{[0.552]}\end{array}$ & $\begin{array}{l}-0.323 \\
{[0.556]}\end{array}$ \\
\hline $\begin{array}{l}\text { Increase in domestic credit, } \\
2004-2007\end{array}$ & & & $\begin{array}{r}0.005 \\
{[0.003]}\end{array}$ & $\begin{array}{r}0.005 \\
{[0.004]}\end{array}$ & & & $\begin{array}{r}0.005 \\
{[0.004]}\end{array}$ & $\begin{array}{r}0.005 \\
{[0.005]}\end{array}$ \\
\hline GDP growth in 2007, WDI & & & $\begin{array}{l}-0.007 \\
{[0.012]}\end{array}$ & $\begin{array}{l}-0.006 \\
{[0.014]}\end{array}$ & & & $\begin{array}{l}-0.007 \\
{[0.013]}\end{array}$ & $\begin{array}{l}-0.007 \\
{[0.015]}\end{array}$ \\
\hline CPI inflation in 2007, WDI & & & $\begin{array}{l}-0.013 \\
{[0.011]}\end{array}$ & $\begin{array}{l}-0.020 \\
{[0.013]}\end{array}$ & & & $\begin{array}{r}-0.013 \\
{[0.012]}\end{array}$ & $\begin{array}{l}-0.020 \\
{[0.013]}\end{array}$ \\
\hline $\begin{array}{l}\text { Chinn-Ito Index, normalized } \\
\text { in } 2007\end{array}$ & & & & $\begin{array}{r}-0.151 \\
{[0.144]}\end{array}$ & & & & $\begin{array}{l}-0.158 \\
{[0.151]}\end{array}$ \\
\hline $\begin{array}{l}\text { Standard \& Poor's sovereign } \\
\text { LCU credit rating in } 2007\end{array}$ & & & & $\begin{array}{r}-0.013 \\
{[0.014]}\end{array}$ & & & & $\begin{array}{r}-0.012 \\
{[0.016]} \\
\end{array}$ \\
\hline Observations & 49 & 48 & 43 & 41 & 49 & 48 & 43 & 41 \\
\hline R-squared & 0.187 & 0.239 & 0.349 & 0.406 & 0.267 & 0.296 & 0.350 & 0.407 \\
\hline
\end{tabular}

$\mathrm{CBS}=$ consolidated banking statistics, $\mathrm{CPI}=$ consumer price index, GDP = gross domestic product, $\mathrm{LBS}=$ locational banking statistics, $\mathrm{LCU}=$ local currency unit, WDI = World Development Indicators.

Notes: The dependent variable is the rate of aggregate capital outflows from each emerging economy after the global financial crisis. The rate of capital outflows is measured using the difference between the maximum and the minimum levels of bilateral foreign claims during the period from the first quarter (Q1) of 2007 to Q3 2008 and the period afterwards, respectively. Measures of direct and indirect exposures are calculated using consolidated banking statistics on immediate counterparty basis. Measures of regional direct and indirect exposures are regional weighted averages using total claims as weights after excluding the country in concern. Average annual percentage change in the real exchange rate is derived by the appreciation rate from the maximum to the minimum values of the real exchange rate where these two extreme values are calculated during January 2003 to December 2007. The real exchange rate is defined as the nominal exchange rate of the domestic currency against the United States (US) dollar deflated by the domestic and the US consumer price indices, respectively. For others, see data description in Appendix Table A1.2. Numbers in brackets are robust standard errors and ${ }^{* * *},{ }^{* *}$, and ${ }^{*}$ denote the significance levels of $1 \%, 5 \%$, and $10 \%$, respectively.

Source: Authors' calculations. 
Table 2 continued

(b) Total cross-border claims of the locational banking statistics (aggregate)

\begin{tabular}{|c|c|c|c|c|c|c|c|c|}
\hline Variables & $\begin{array}{l}\text { (1) } \\
\text { Outflow }\end{array}$ & $\begin{array}{l}\text { (2) } \\
\text { Outflow }\end{array}$ & $\begin{array}{l}\text { (3) } \\
\text { Outflow }\end{array}$ & $\begin{array}{l}\text { (4) } \\
\text { Outflow }\end{array}$ & $\begin{array}{l}\text { (5) } \\
\text { Outflow }\end{array}$ & $\begin{array}{l}\text { (6) } \\
\text { Outflow }\end{array}$ & $\begin{array}{l}\text { (7) } \\
\text { Outflow }\end{array}$ & $\begin{array}{l}\text { (8) } \\
\text { Outflow }\end{array}$ \\
\hline $\begin{array}{l}\text { Direct exposure of the } \\
\text { entire sector (LBS) in } 2007\end{array}$ & $\begin{array}{l}0.316^{* *} \\
{[0.152]}\end{array}$ & $\begin{array}{r}0.036 \\
{[0.179]}\end{array}$ & $\begin{array}{r}0.044 \\
{[0.163]}\end{array}$ & $\begin{array}{r}-0.111 \\
{[0.258]}\end{array}$ & $\begin{array}{r}0.118 \\
{[0.153]}\end{array}$ & $\begin{array}{r}-0.117 \\
{[0.166]}\end{array}$ & $\begin{array}{l}-0.088 \\
{[0.176]}\end{array}$ & $\begin{array}{r}-0.147 \\
{[0.242]}\end{array}$ \\
\hline $\begin{array}{l}\text { Regional direct exposure } \\
\text { of the entire sector (LBS) } \\
\text { in } 2007\end{array}$ & & $\begin{array}{l}0.887^{* *} \\
{[0.385]}\end{array}$ & $\begin{array}{r}0.377 \\
{[0.355]}\end{array}$ & $\begin{array}{r}0.441 \\
{[0.428]}\end{array}$ & & $\begin{array}{r}0.547 \\
{[0.333]}\end{array}$ & $\begin{array}{r}0.274 \\
{[0.366]}\end{array}$ & $\begin{array}{r}0.337 \\
{[0.451]}\end{array}$ \\
\hline $\begin{array}{l}\text { Indirect exposure of the } \\
\text { entire sector (LBS) in } 2007\end{array}$ & & & & & $\begin{array}{l}1.842^{* * *} \\
{[0.515]}\end{array}$ & $\begin{array}{r}0.111 \\
{[0.736]}\end{array}$ & $\begin{array}{r}0.249 \\
{[0.748]}\end{array}$ & $\begin{array}{r}0.163 \\
{[0.813]}\end{array}$ \\
\hline $\begin{array}{l}\text { Regional indirect exposure } \\
\text { of the entire sector (LBS) } \\
\text { in } 2007\end{array}$ & & & & & & $\begin{array}{r}3.358^{* * *} \\
{[1.195]}\end{array}$ & $\begin{array}{l}2.449^{*} \\
{[1.243]}\end{array}$ & $\begin{array}{r}2.413 \\
{[1.455]}\end{array}$ \\
\hline $\begin{array}{l}\text { Aggravation of current } \\
\text { account balance } \\
\text { 2004-2007 }\end{array}$ & & & $\begin{array}{l}-0.002 \\
{[0.007]}\end{array}$ & $\begin{array}{l}-0.003 \\
{[0.007]}\end{array}$ & & & $\begin{array}{l}-0.004 \\
{[0.006]}\end{array}$ & $\begin{array}{l}-0.004 \\
{[0.007]}\end{array}$ \\
\hline $\begin{array}{l}\text { Average annual percentage } \\
\text { change in the real exchange } \\
\text { rate, 2005-2007 }\end{array}$ & & & $\begin{array}{c}-0.931^{* *} \\
{[0.394]}\end{array}$ & $\begin{array}{l}-0.759^{*} \\
{[0.420]}\end{array}$ & & & $\begin{array}{r}-0.796^{* *} \\
{[0.339]}\end{array}$ & $\begin{array}{l}-0.635^{*} \\
{[0.370]}\end{array}$ \\
\hline $\begin{array}{l}\text { Increase in domestic credit, } \\
2004-2007\end{array}$ & & & $\begin{array}{r}0.006^{*} \\
{[0.003]}\end{array}$ & $\begin{array}{r}0.004 \\
{[0.003]}\end{array}$ & & & $\begin{array}{r}0.003 \\
{[0.003]}\end{array}$ & $\begin{array}{r}0.002 \\
{[0.003]}\end{array}$ \\
\hline GDP growth in 2007, WDI & & & $\begin{array}{r}0.006 \\
{[0.017]}\end{array}$ & $\begin{array}{r}0.005 \\
{[0.015]}\end{array}$ & & & $\begin{array}{r}0.001 \\
{[0.015]}\end{array}$ & $\begin{array}{r}0.002 \\
{[0.013]}\end{array}$ \\
\hline CPI inflation in 2007, WDI & & & $\begin{array}{r}0.005 \\
{[0.008]}\end{array}$ & $\begin{array}{r}0.015 \\
{[0.011]}\end{array}$ & & & $\begin{array}{r}0.006 \\
{[0.008]}\end{array}$ & $\begin{array}{r}0.009 \\
{[0.011]}\end{array}$ \\
\hline $\begin{array}{l}\text { Chinn-Ito Index, normalized } \\
\text { in } 2007\end{array}$ & & & & $\begin{array}{r}0.063 \\
{[0.089]}\end{array}$ & & & & $\begin{array}{r}0.056 \\
{[0.087]}\end{array}$ \\
\hline $\begin{array}{l}\text { Standard \& Poor's sovereign } \\
\text { LCU credit rating in } 2007\end{array}$ & & & & $\begin{array}{r}0.015 \\
{[0.012]} \\
\end{array}$ & & & & $\begin{array}{r}0.002 \\
{[0.013]} \\
\end{array}$ \\
\hline Observations & 49 & 48 & 43 & 41 & 49 & 48 & 43 & 41 \\
\hline R-squared & 0.050 & 0.153 & 0.418 & 0.448 & 0.202 & 0.413 & 0.536 & 0.540 \\
\hline
\end{tabular}

$\mathrm{CPI}=$ consumer price index, GDP = gross domestic product, $\mathrm{LBS}=$ locational banking statistics, $\mathrm{LCU}=$ local currency unit, WDI = World Development Indicators.

Notes: The dependent variable is the rate of aggregate capital outflows from each emerging economy after the global financial crisis. Measures of (regional) direct/indirect exposures are calculated using the locational banking statistics' total cross-border claims.

For others, the dependent variable is the rate of aggregate capital outflows from each emerging economy after the global financial crisis. The rate of capital outflows is measured using the difference between the maximum and the minimum levels of bilateral foreign claims during the period from the first quarter (Q1) of 2007 to Q3 2008 and the period afterwards, respectively. Measures of direct and indirect exposures are calculated using consolidated banking statistics on immediate counterparty basis. Measures of regional direct and indirect exposures are regional weighted averages using total claims as weights after excluding the country in concern. Average annual percentage change in the real exchange rate is derived by the appreciation rate from the maximum to the minimum values of the real exchange rate where these two extreme values are calculated during January 2003 to December 2007. The real exchange rate is defined as the nominal exchange rate of the domestic currency against the United States (US) dollar deflated by the domestic and the US consumer price indices, respectively. For others, see data description in Appendix Table A1.2. Numbers in brackets are robust standard errors and ${ }^{* * *},{ }^{* *}$, and $^{*}$ denote the significance levels of $1 \%, 5 \%$, and $10 \%$, respectively.

Source: Authors' calculations. 
Table 2 continued

(c) Total foreign claims of the consolidated banking statistic on immediate counterparty basis (bilateral)

\begin{tabular}{|c|c|c|c|c|c|c|c|c|}
\hline Variables & $\begin{array}{c}(1) \\
\text { Outflow }\end{array}$ & $\begin{array}{c}\text { (2) } \\
\text { Outflow }\end{array}$ & $\begin{array}{l}(3) \\
\text { Outflow }\end{array}$ & $\begin{array}{c}\text { (4) } \\
\text { Outflow }\end{array}$ & $\begin{array}{c}\text { (5) } \\
\text { Outflow }\end{array}$ & $\begin{array}{c}(6) \\
\text { Outflow }\end{array}$ & $\begin{array}{c}(7) \\
\text { Outflow }\end{array}$ & $\begin{array}{c}\text { (8) } \\
\text { Outflow }\end{array}$ \\
\hline $\begin{array}{l}\text { Direct exposure of the entire } \\
\text { sector on immediate } \\
\text { counterparty basis (CBS) } \\
\text { in } 2007\end{array}$ & $\begin{array}{l}0.325^{* *} \\
{[0.149]}\end{array}$ & $\begin{array}{c}0.441^{* *} \\
{[0.202]}\end{array}$ & $\begin{array}{r}0.351 \\
{[0.217]}\end{array}$ & $\begin{array}{r}0.336 \\
{[0.219]}\end{array}$ & $\begin{array}{l}0.332^{* *} \\
{[0.150]}\end{array}$ & $\begin{array}{l}0.494^{* *} \\
{[0.210]}\end{array}$ & $\begin{array}{r}0.339 \\
{[0.230]}\end{array}$ & $\begin{array}{r}0.281 \\
{[0.235]}\end{array}$ \\
\hline $\begin{array}{l}\text { Regional direct exposure } \\
\text { of the entire sector on } \\
\text { immediate counterparty } \\
\text { basis (CBS) in } 2007\end{array}$ & & $\begin{array}{l}-0.301 \\
{[0.319]}\end{array}$ & $\begin{array}{r}-0.437 \\
{[0.346]}\end{array}$ & $\begin{array}{l}-0.637^{*} \\
{[0.352]}\end{array}$ & & $\begin{array}{r}-0.393 \\
{[0.345]}\end{array}$ & $\begin{array}{r}-0.431 \\
{[0.365]}\end{array}$ & $\begin{array}{r}-0.519 \\
{[0.366]}\end{array}$ \\
\hline $\begin{array}{l}\text { Indirect exposure of the } \\
\text { entire sector on immediate } \\
\text { counterparty basis (CBS) } \\
\text { in } 2007\end{array}$ & & & & & $\begin{array}{r}0.359 \\
{[0.712]}\end{array}$ & $\begin{array}{r}0.693 \\
{[0.777]}\end{array}$ & $\begin{array}{r}-0.138 \\
{[0.988]}\end{array}$ & $\begin{array}{l}-1.048 \\
{[1.047]}\end{array}$ \\
\hline $\begin{array}{l}\text { Regional indirect exposure of } \\
\text { the entire sector on } \\
\text { immediate counterparty } \\
\text { basis (CBS) in } 2007\end{array}$ & & & & & & $\begin{array}{r}-0.060 \\
{[1.733]}\end{array}$ & $\begin{array}{r}0.114 \\
{[2.006]}\end{array}$ & $\begin{array}{r}-0.933 \\
{[2.093]}\end{array}$ \\
\hline Dummy of same region & $\begin{array}{r}-0.210^{* * *} \\
{[0.049]}\end{array}$ & $\begin{array}{r}-0.236^{* * *} \\
{[0.059]}\end{array}$ & $\begin{array}{r}-0.264^{* * *} \\
{[0.058]}\end{array}$ & $\begin{array}{r}-0.269^{* * *} \\
{[0.056]}\end{array}$ & $\begin{array}{r}-0.210^{* * *} \\
{[0.049]}\end{array}$ & $\begin{array}{r}-0.239^{* * *} \\
{[0.059]}\end{array}$ & $\begin{array}{r}-0.264^{* * *} \\
{[0.059]}\end{array}$ & $\begin{array}{r}-0.262^{* * *} \\
{[0.058]}\end{array}$ \\
\hline $\begin{array}{l}\text { Aggravation of current } \\
\text { account balance 2004-2007 }\end{array}$ & & & $\begin{array}{r}-0.002 \\
{[0.004]}\end{array}$ & $\begin{array}{r}-0.000 \\
{[0.004]}\end{array}$ & & & $\begin{array}{l}-0.002 \\
{[0.004]}\end{array}$ & $\begin{array}{r}0.000 \\
{[0.004]}\end{array}$ \\
\hline $\begin{array}{l}\text { Average annual percentage } \\
\text { change in the real exchange } \\
\text { rate, 2005-2007 }\end{array}$ & & & $\begin{array}{r}0.099 \\
{[0.273]}\end{array}$ & $\begin{array}{r}0.173 \\
{[0.274]}\end{array}$ & & & $\begin{array}{r}0.103 \\
{[0.284]}\end{array}$ & $\begin{array}{r}0.103 \\
{[0.284]}\end{array}$ \\
\hline $\begin{array}{l}\text { Increase in domestic credit, } \\
2004-2007\end{array}$ & & & $\begin{array}{c}0.002^{*} \\
{[0.001]}\end{array}$ & $\begin{array}{c}0.003^{*} \\
{[0.001]}\end{array}$ & & & $\begin{array}{c}0.002^{*} \\
{[0.001]}\end{array}$ & $\begin{array}{l}0.003^{* *} \\
{[0.002]}\end{array}$ \\
\hline GDP growth in 2007, WDI & & & $\begin{array}{r}0.002 \\
{[0.006]}\end{array}$ & $\begin{array}{r}0.005 \\
{[0.006]}\end{array}$ & & & $\begin{array}{r}0.002 \\
{[0.006]}\end{array}$ & $\begin{array}{r}0.005 \\
{[0.006]}\end{array}$ \\
\hline CPI inflation in 2007, WDI & & & $\begin{array}{r}0.005 \\
{[0.005]}\end{array}$ & $\begin{array}{r}0.010^{*} \\
{[0.006]}\end{array}$ & & & $\begin{array}{r}0.005 \\
{[0.005]}\end{array}$ & $\begin{array}{r}0.010 \\
{[0.006]}\end{array}$ \\
\hline $\begin{array}{l}\text { Chinn-Ito Index, normalized } \\
\text { in } 2007\end{array}$ & & & & $\begin{array}{r}0.117^{* *} \\
{[0.048]}\end{array}$ & & & & $\begin{array}{l}0.137^{* * *} \\
{[0.049]}\end{array}$ \\
\hline $\begin{array}{l}\text { Standard \& Poor's sovereign } \\
\text { LCU credit rating in } 2007\end{array}$ & & & & $\begin{array}{r}0.006 \\
{[0.006]}\end{array}$ & & & & $\begin{array}{r}0.006 \\
{[0.007]}\end{array}$ \\
\hline Observations & 571 & 554 & 498 & 482 & 571 & 554 & 498 & 482 \\
\hline R-squared & 0.038 & 0.038 & 0.063 & 0.082 & 0.038 & 0.040 & 0.063 & 0.085 \\
\hline
\end{tabular}

$\mathrm{CBS}=$ consolidated banking statistics, $\mathrm{CPI}=$ consumer price index, $\mathrm{GDP}=$ gross domestic product, $\mathrm{LCU}=$ local currency unit, WDI $=\mathrm{World}$ Development Indicators.

Notes: The dependent variable is the rate of bilateral capital outflows from each emerging economy to each reporting country after the global financial crisis. Dummy of the same region takes one if the reporting country belongs to the same region as the emerging economy. For others, the dependent variable is the rate of aggregate capital outflows from each emerging economy after the global financial crisis. The rate of capital outflows is measured using the difference between the maximum and the minimum levels of bilateral foreign claims during the period from the first quarter (Q1) of 2007 to Q3 2008 and the period afterwards, respectively. Measures of direct and indirect exposures are calculated using consolidated banking statistics on immediate counterparty basis. Measures of regional direct and indirect exposures are regional weighted averages using total claims as weights after excluding the country in concern. Average annual percentage change in the real exchange rate is derived by the appreciation rate from the maximum to the minimum values of the real exchange rate where these two extreme values are calculated during January 2003 to December 2007. The real exchange rate is defined as the nominal exchange rate of the domestic currency against the United States (US) dollar deflated by the domestic and the US consumer price indices, respectively. For others, see data description in Appendix Table A1.2. Numbers in brackets are robust standard errors and ${ }^{* * *},{ }^{* *}$, and ${ }^{*}$ denote the significance levels of $1 \%, 5 \%$, and $10 \%$, respectively.

Source: Authors' calculations. 
Table 2 continued

(d) Total cross-border claims of the locational banking statistics (bilateral)

\begin{tabular}{|c|c|c|c|c|c|c|c|c|}
\hline Variables & $\begin{array}{c}(1) \\
\text { Outflow }\end{array}$ & $\begin{array}{c}\text { (2) } \\
\text { Outflow }\end{array}$ & $\begin{array}{c}\text { (3) } \\
\text { Outflow }\end{array}$ & $\begin{array}{c}(4) \\
\text { Outflow }\end{array}$ & $\begin{array}{l}(5) \\
\text { Outflow }\end{array}$ & $\begin{array}{c}(6) \\
\text { Outflow }\end{array}$ & $\begin{array}{c}\text { (7) } \\
\text { Outflow }\end{array}$ & $\begin{array}{c}(8) \\
\text { Outflow }\end{array}$ \\
\hline $\begin{array}{l}\text { Direct exposure of the } \\
\text { entire sector (LBS) in } 2007\end{array}$ & $\begin{array}{r}0.117 \\
{[0.077]}\end{array}$ & $\begin{array}{r}0.021 \\
{[0.101]}\end{array}$ & $\begin{array}{l}-0.026 \\
{[0.108]}\end{array}$ & $\begin{array}{l}-0.052 \\
{[0.127]}\end{array}$ & $\begin{array}{r}0.100 \\
{[0.082]}\end{array}$ & $\begin{array}{r}0.004 \\
{[0.101]}\end{array}$ & $\begin{array}{l}-0.034 \\
{[0.108]}\end{array}$ & $\begin{array}{l}-0.055 \\
{[0.125]}\end{array}$ \\
\hline $\begin{array}{l}\text { Regional direct exposure } \\
\text { of the entire sector (LBS) } \\
\text { in } 2007\end{array}$ & & $\begin{array}{r}0.402^{* *} \\
{[0.171]}\end{array}$ & $\begin{array}{r}0.211 \\
{[0.185]}\end{array}$ & $\begin{array}{r}0.256 \\
{[0.211]}\end{array}$ & & $\begin{array}{c}0.324^{*} \\
{[0.176]}\end{array}$ & $\begin{array}{r}0.203 \\
{[0.187]}\end{array}$ & $\begin{array}{r}0.248 \\
{[0.215]}\end{array}$ \\
\hline $\begin{array}{l}\text { Indirect exposure of the } \\
\text { entire sector (LBS) in } 2007\end{array}$ & & & & & $\begin{array}{r}0.149 \\
{[0.255]}\end{array}$ & $\begin{array}{l}-0.442 \\
{[0.360]}\end{array}$ & $\begin{array}{l}-0.066 \\
{[0.427]}\end{array}$ & $\begin{array}{l}-0.200 \\
{[0.441]}\end{array}$ \\
\hline $\begin{array}{l}\text { Regional indirect exposure } \\
\text { of the entire sector (LBS) } \\
\text { in } 2007\end{array}$ & & & & & & $\begin{array}{r}1.147^{* *} \\
{[0.465]}\end{array}$ & $\begin{array}{r}0.210 \\
{[0.574]}\end{array}$ & $\begin{array}{r}0.447 \\
{[0.650]}\end{array}$ \\
\hline Dummy of same region & $\begin{array}{l}-0.066^{*} \\
{[0.038]}\end{array}$ & $\begin{array}{r}0.013 \\
{[0.042]}\end{array}$ & $\begin{array}{r}-0.016 \\
{[0.047]}\end{array}$ & $\begin{array}{r}-0.019 \\
{[0.046]}\end{array}$ & $\begin{array}{l}-0.066^{*} \\
{[0.039]}\end{array}$ & $\begin{array}{r}0.012 \\
{[0.042]}\end{array}$ & $\begin{array}{r}-0.017 \\
{[0.047]}\end{array}$ & $\begin{array}{r}-0.019 \\
{[0.047]}\end{array}$ \\
\hline $\begin{array}{l}\text { Aggravation of current } \\
\text { account balance } \\
\text { 2004-2007 }\end{array}$ & & & $\begin{array}{r}-0.001 \\
{[0.003]}\end{array}$ & $\begin{array}{r}-0.001 \\
{[0.003]}\end{array}$ & & & $\begin{array}{l}-0.002 \\
{[0.003]}\end{array}$ & $\begin{array}{r}-0.001 \\
{[0.003]}\end{array}$ \\
\hline $\begin{array}{l}\text { Average annual percentage } \\
\text { change in the real exchange } \\
\text { rate, 2005-2007 }\end{array}$ & & & $\begin{array}{r}0.067 \\
{[0.217]}\end{array}$ & $\begin{array}{r}0.155 \\
{[0.222]}\end{array}$ & & & $\begin{array}{r}0.069 \\
{[0.219]}\end{array}$ & $\begin{array}{r}0.159 \\
{[0.224]}\end{array}$ \\
\hline $\begin{array}{l}\text { Increase in domestic credit, } \\
2004-2007\end{array}$ & & & $\begin{array}{r}0.004^{* * *} \\
{[0.001]}\end{array}$ & $\begin{array}{r}0.004^{* * *} \\
{[0.001]}\end{array}$ & & & $\begin{array}{r}0.004^{* * *} \\
{[0.001]}\end{array}$ & $\begin{array}{r}0.004^{* * *} \\
{[0.001]}\end{array}$ \\
\hline GDP growth in 2007, WDI & & & $\begin{array}{r}0.001 \\
{[0.005]}\end{array}$ & $\begin{array}{r}0.002 \\
{[0.005]}\end{array}$ & & & $\begin{array}{r}0.000 \\
{[0.005]}\end{array}$ & $\begin{array}{r}0.001 \\
{[0.005]}\end{array}$ \\
\hline CPI inflation in 2007, WDI & & & $\begin{array}{r}0.001 \\
{[0.004]}\end{array}$ & $\begin{array}{r}0.001 \\
{[0.005]}\end{array}$ & & & $\begin{array}{r}0.001 \\
{[0.004]}\end{array}$ & $\begin{array}{l}-0.000 \\
{[0.005]}\end{array}$ \\
\hline $\begin{array}{l}\text { Chinn-Ito Index, normalized } \\
\text { in } 2007\end{array}$ & & & & $\begin{array}{r}0.019 \\
{[0.039]}\end{array}$ & & & & $\begin{array}{r}0.018 \\
{[0.039]}\end{array}$ \\
\hline $\begin{array}{l}\text { Standard \& Poor'sovereign } \\
\text { LCU credit rating in } 2007\end{array}$ & & & & $\begin{array}{r}-0.002 \\
{[0.005]}\end{array}$ & & & & $\begin{array}{r}-0.003 \\
{[0.006]}\end{array}$ \\
\hline Observations & 850 & 828 & 736 & 707 & 850 & 828 & 736 & 707 \\
\hline R-squared & 0.007 & 0.014 & 0.041 & 0.043 & 0.008 & 0.021 & 0.041 & 0.044 \\
\hline
\end{tabular}

$\mathrm{CPI}=$ consumer price index, GDP = gross domestic product, $\mathrm{LBS}=$ locational banking statistics, $\mathrm{LCU}=$ local currency unit, WDI = World Development Indicators.

Notes: The dependent variable is the rate of bilateral capital outflows from each emerging economy to each reporting country after the global financial crisis. Dummy of the same region takes one if the reporting country belongs to the same region as the emerging economy. For others, the dependent variable is the rate of aggregate capital outflows from each emerging economy after the global financial crisis. The rate of capital outflows is measured using the difference between the maximum and the minimum levels of bilateral foreign claims during the period from the first quarter (Q1) of 2007 to Q3 2008 and the period afterwards, respectively. Measures of direct and indirect exposures are calculated using consolidated banking statistics on immediate counterparty basis. Measures of regional direct and indirect exposures are regional weighted averages using total claims as weights after excluding the country in concern. Average annual percentage change in the real exchange rate is derived by the appreciation rate from the maximum to the minimum values of the real exchange rate where these two extreme values are calculated during January 2003 to December 2007. The real exchange rate is defined as the nominal exchange rate of the domestic currency against the United States (US) dollar deflated by the domestic and the US consumer price indices, respectively. For others, see data description in Appendix Table A1.2. Numbers in brackets are robust standard errors and ${ }^{* * *},{ }^{* *}$, and ${ }^{*}$ denote the significance levels of $1 \%, 5 \%$, and $10 \%$, respectively.

Source: Authors' calculations. 
It is interesting to note that the regression results based on the LBS, but not based on the CBS, generate evidence of contagion effects at the regional level in capital outflows. Minoiu and Reyes (2011) argue that the LBS are best suited for analyzing geographical interlinkages by capturing "net flows of financial capital between any two regions channeled through the banking system" (McGuire and Tarashev 2006, 34). As the LBS reports activities of all foreign as well as domestic banks at locational basis, they argue it will present a more accurate picture for sudden withdrawals of foreign claims to the extent that foreign banks play a more important role than domestic ones in any given location. Bruno and Shin (2015) also point out that the LBS are particularly useful in evaluating the role of banks in the intermediation of international capital flows, as the intragroup positions in multiple countries are not netted out. Even withdrawals of claims from affiliates to the headquarters within the same group are capital outflows from the perspective of the emerging economy, and hence can create adverse impacts. Our results indicate that contagion effects are more pronounced when exposure measures take all the intragroup transactions into consideration.

Table 3 reports regression results from estimating equation (11) that focuses on banking sector exposures. We have two regression results for aggregate banking flows based on the exposures calculated using the CBS (Table 3a) and the LBS (Table 3b), respectively. We also report two regression results for bilateral banking flows based on the exposures calculated using the CBS (Table 3c) and the LBS (Table 3d), respectively.

Table 3a shows somewhat weaker results only in the sense that increase in domestic credit has a consistently positive impact, with statistical significance. However, Table 3b, which is based on the LBS, presents even stronger evidence of contagion effects at the regional level. The coefficient of the regional direct exposure is statistically significant at the $1 \%$ or $5 \%$ level in columns (2) and (6) and the coefficient of the regional indirect exposure is statistically significant at least at the $10 \%$ level in all columns (6)-(8). Table 3c, which is based on the bilateral banking outflows of the CBS, shows that the country's own direct and indirect exposures are significant in explaining capital outflows. The coefficient of the same region dummy is again negative, with high statistical significance. Table $3 d$, which is based on the bilateral capital outflows of the LBS, again presents much stronger evidence of contagion effects at the regional level. The coefficient of the regional direct exposure is always positive and statistically significant at least at the $10 \%$ level.

Finally, Table 4 reports regression results from equation (12), which focuses on exposures of short-term claims. Unfortunately, sectoral decomposition of claims by maturity is available only for the CBS. In Table 4a, based on aggregate banking flows, the coefficients of direct/indirect exposures are always positive, but statistically significant in columns (1), (2), (5), and (6). In Table 4b, based on bilateral banking flows, no coefficient of direct/indirect and regional direct/indirect exposures are statistically significant, while the coefficient of the same region dummy is negative, with high statistical significance. There is also evidence that an increase in domestic credit and capital market liberalization positively influences capital outflows. 
Table 3: Contagion Effects in Capital Outflows Due to Exposures of the Banking Sector

(a) Banking sector claims based on the consolidated on ultimate risk basis (aggregate)

\begin{tabular}{|c|c|c|c|c|c|c|c|c|}
\hline Variables & $\begin{array}{c}(1) \\
\text { Outflow }\end{array}$ & $\begin{array}{c}\text { (2) } \\
\text { Outflow }\end{array}$ & $\begin{array}{c}\text { (3) } \\
\text { Outflow }\end{array}$ & $\begin{array}{c}\text { (4) } \\
\text { Outflow }\end{array}$ & $\begin{array}{c}\text { (5) } \\
\text { Outflow }\end{array}$ & $\begin{array}{c}\text { (6) } \\
\text { Outflow }\end{array}$ & $\begin{array}{c}\text { (7) } \\
\text { Outflow }\end{array}$ & $\begin{array}{l}\text { (8) } \\
\text { Outflow }\end{array}$ \\
\hline $\begin{array}{l}\text { Direct exposure of the } \\
\text { banking sector (CBS) } \\
\text { in } 2007\end{array}$ & $\begin{array}{r}0.347 \\
{[0.387]}\end{array}$ & $\begin{array}{r}0.167 \\
{[0.492]}\end{array}$ & $\begin{array}{r}0.709 \\
{[0.517]}\end{array}$ & $\begin{array}{r}0.757 \\
{[0.642]}\end{array}$ & $\begin{array}{r}0.524 \\
{[0.396]}\end{array}$ & $\begin{array}{r}0.299 \\
{[0.489]}\end{array}$ & $\begin{array}{r}0.704 \\
{[0.517]}\end{array}$ & $\begin{array}{r}0.697 \\
{[0.681]}\end{array}$ \\
\hline $\begin{array}{l}\text { Regional direct exposure } \\
\text { of the banking sector (CBS) } \\
\text { in } 2007\end{array}$ & & $\begin{array}{r}0.291 \\
{[0.508]}\end{array}$ & $\begin{array}{l}-0.070 \\
{[0.398]}\end{array}$ & $\begin{array}{r}0.031 \\
{[0.431]}\end{array}$ & & $\begin{array}{r}0.457 \\
{[0.669]}\end{array}$ & $\begin{array}{r}0.072 \\
{[0.498]}\end{array}$ & $\begin{array}{r}0.242 \\
{[0.575]}\end{array}$ \\
\hline $\begin{array}{l}\text { Indirect exposure of the } \\
\text { banking sector (CBS) } \\
\text { in } 2007\end{array}$ & & & & & $\begin{array}{r}2.875 \\
{[1.973]}\end{array}$ & $\begin{array}{r}2.957 \\
{[2.209]}\end{array}$ & $\begin{array}{l}-0.474 \\
{[2.975]}\end{array}$ & $\begin{array}{r}0.517 \\
{[3.237]}\end{array}$ \\
\hline $\begin{array}{l}\text { Regional indirect exposure } \\
\text { of the banking sector (CBS) } \\
\text { in } 2007\end{array}$ & & & & & & $\begin{array}{r}1.935 \\
{[7.480]}\end{array}$ & $\begin{array}{r}4.847 \\
{[7.066]}\end{array}$ & $\begin{array}{r}6.045 \\
{[7.859]}\end{array}$ \\
\hline $\begin{array}{l}\text { Aggravation of current } \\
\text { account balance } \\
2004-2007\end{array}$ & & & $\begin{array}{r}-0.012 \\
{[0.008]}\end{array}$ & $\begin{array}{r}-0.013 \\
{[0.008]}\end{array}$ & & & $\begin{array}{r}-0.012 \\
{[0.009]}\end{array}$ & $\begin{array}{r}-0.013 \\
{[0.009]}\end{array}$ \\
\hline $\begin{array}{l}\text { Average annual percentage } \\
\text { change in the real exchange } \\
\text { rate, } 2005-2007\end{array}$ & & & $\begin{array}{r}-0.556 \\
{[0.602]}\end{array}$ & $\begin{array}{r}-0.617 \\
{[0.554]}\end{array}$ & & & $\begin{array}{r}-0.613 \\
{[0.652]}\end{array}$ & $\begin{array}{l}-0.608 \\
{[0.610]}\end{array}$ \\
\hline $\begin{array}{l}\text { Increase in domestic credit, } \\
2004-2007\end{array}$ & & & $\begin{array}{l}0.007^{* *} \\
{[0.003]}\end{array}$ & $\begin{array}{r}0.007^{*} \\
{[0.004]}\end{array}$ & & & $\begin{array}{r}0.007^{*} \\
{[0.004]}\end{array}$ & $\begin{array}{r}0.007 \\
{[0.004]}\end{array}$ \\
\hline GDP growth in 2007, WDI & & & $\begin{array}{l}-0.009 \\
{[0.014]}\end{array}$ & $\begin{array}{l}-0.009 \\
{[0.016]}\end{array}$ & & & $\begin{array}{l}-0.009 \\
{[0.015]}\end{array}$ & $\begin{array}{l}-0.010 \\
{[0.018]}\end{array}$ \\
\hline CPI inflation in 2007, WDI & & & $\begin{array}{r}-0.015 \\
{[0.012]}\end{array}$ & $\begin{array}{l}-0.020 \\
{[0.014]}\end{array}$ & & & $\begin{array}{r}-0.014 \\
{[0.012]}\end{array}$ & $\begin{array}{l}-0.022 \\
{[0.015]}\end{array}$ \\
\hline $\begin{array}{l}\text { Chinn-Ito Index, normalized } \\
\text { in } 2007\end{array}$ & & & & $\begin{array}{r}-0.118 \\
{[0.167]}\end{array}$ & & & & $\begin{array}{l}-0.105 \\
{[0.173]}\end{array}$ \\
\hline $\begin{array}{l}\text { Standard \& Poor's sovereign } \\
\text { LCU credit rating in } 2007\end{array}$ & & & & $\begin{array}{l}-0.008 \\
{[0.018]}\end{array}$ & & & & $\begin{array}{r}-0.013 \\
{[0.022]}\end{array}$ \\
\hline Observations & 48 & 47 & 43 & 41 & 48 & 47 & 43 & 41 \\
\hline R-squared & 0.016 & 0.025 & 0.240 & 0.262 & 0.044 & 0.058 & 0.251 & 0.277 \\
\hline
\end{tabular}

$\mathrm{CBS}=$ consolidated banking statistics, $\mathrm{CPI}=$ consumer price index, $\mathrm{GDP}=$ gross domestic product, $\mathrm{LCU}=$ local currency unit, $\mathrm{WDI}=$ World Development Indicators.

Notes: The dependent variable is the rate of aggregate capital outflows from each emerging economy after the global financial crisis. Measures of (regional) direct and indirect exposures are calculated using total foreign claims on the banking sector based on consolidated banking statistics on ultimate risk basis.

The rate of capital outflows is measured using the difference between the maximum and the minimum levels of bilateral foreign claims during the period from the first quarter (Q1) of 2007 to Q3 2008 and the period afterwards, respectively. Measures of direct and indirect exposures are calculated using consolidated banking statistics on immediate counterparty basis. Measures of regional direct and indirect exposures are regional weighted averages using total claims as weights after excluding the country in concern. Average annual percentage change in the real exchange rate is derived by the appreciation rate from the maximum to the minimum values of the real exchange rate where these two extreme values are calculated during January 2003 to December 2007. The real exchange rate is defined as the nominal exchange rate of the domestic currency against the United States (US) dollar deflated by the domestic and the US consumer price indices, respectively. For others, see data description in Appendix Table A1.2. Numbers in brackets are robust standard errors and ${ }^{* * *},{ }^{* *}$, and ${ }^{*}$ denote the significance levels of $1 \%, 5 \%$, and $10 \%$, respectively.

Source: Authors' calculations. 
Table 3 continued

(b) Banking sector claims based on the locational banking statistics (aggregate)

\begin{tabular}{|c|c|c|c|c|c|c|c|c|}
\hline Variables & $\begin{array}{c}\text { (1) } \\
\text { Outflow }\end{array}$ & $\begin{array}{c}\text { (2) } \\
\text { Outflow }\end{array}$ & $\begin{array}{c}\text { (3) } \\
\text { Outflow }\end{array}$ & $\begin{array}{c}\text { (4) } \\
\text { Outflow }\end{array}$ & $\begin{array}{c}\text { (5) } \\
\text { Outflow }\end{array}$ & $\begin{array}{c}\text { (6) } \\
\text { Outflow }\end{array}$ & $\begin{array}{c}\text { (7) } \\
\text { Outflow }\end{array}$ & $\begin{array}{c}\text { (8) } \\
\text { Outflow }\end{array}$ \\
\hline $\begin{array}{l}\text { Direct exposure of the } \\
\text { banking sector (LBS) } \\
\text { in } 2007\end{array}$ & $\begin{array}{r}0.129 \\
{[0.105]}\end{array}$ & $\begin{array}{r}-0.019 \\
{[0.096]}\end{array}$ & $\begin{array}{r}-0.004 \\
{[0.105]}\end{array}$ & $\begin{array}{l}-0.061 \\
{[0.139]}\end{array}$ & $\begin{array}{r}0.156 \\
{[0.101]}\end{array}$ & $\begin{array}{r}-0.072 \\
{[0.110]}\end{array}$ & $\begin{array}{l}-0.045 \\
{[0.132]}\end{array}$ & $\begin{array}{r}-0.038 \\
{[0.161]}\end{array}$ \\
\hline $\begin{array}{l}\text { Regional direct exposure } \\
\text { of the banking sector (LBS) } \\
\text { in } 2007\end{array}$ & & $\begin{array}{l}1.071^{* * *} \\
{[0.332]}\end{array}$ & $\begin{array}{r}0.442 \\
{[0.326]}\end{array}$ & $\begin{array}{r}0.421 \\
{[0.375]}\end{array}$ & & $\begin{array}{l}0.659^{* *} \\
{[0.281]}\end{array}$ & $\begin{array}{r}0.269 \\
{[0.340]}\end{array}$ & $\begin{array}{r}0.210 \\
{[0.440]}\end{array}$ \\
\hline $\begin{array}{l}\text { Indirect exposure of the } \\
\text { banking sector (LBS) } \\
\text { in } 2007\end{array}$ & & & & & $\begin{array}{c}1.095^{* * *} \\
{[0.299]}\end{array}$ & $\begin{array}{r}0.374 \\
{[0.336]}\end{array}$ & $\begin{array}{r}0.292 \\
{[0.410]}\end{array}$ & $\begin{array}{r}0.314 \\
{[0.421]}\end{array}$ \\
\hline $\begin{array}{l}\text { Regional indirect exposure } \\
\text { of the banking sector (LBS) } \\
\text { in } 2007\end{array}$ & & & & & & $\begin{array}{l}1.928^{* * *} \\
{[0.580]}\end{array}$ & $\begin{array}{c}1.551^{* *} \\
{[0.715]}\end{array}$ & $\begin{array}{r}1.409^{*} \\
{[0.765]}\end{array}$ \\
\hline $\begin{array}{l}\text { Aggravation of current } \\
\text { account balance } \\
\text { 2004-2007 }\end{array}$ & & & $\begin{array}{r}-0.002 \\
{[0.006]}\end{array}$ & $\begin{array}{r}-0.003 \\
{[0.006]}\end{array}$ & & & $\begin{array}{r}-0.004 \\
{[0.006]}\end{array}$ & $\begin{array}{r}-0.003 \\
{[0.006]}\end{array}$ \\
\hline $\begin{array}{l}\text { Average annual percentage } \\
\text { change in the real exchange } \\
\text { rate, } 2005-2007\end{array}$ & & & $\begin{array}{r}-0.880^{* *} \\
{[0.398]}\end{array}$ & $\begin{array}{l}-0.749^{*} \\
{[0.420]}\end{array}$ & & & $\begin{array}{l}-0.741^{*} \\
{[0.368]}\end{array}$ & $\begin{array}{r}-0.615 \\
{[0.383]}\end{array}$ \\
\hline $\begin{array}{l}\text { Increase in domestic credit, } \\
2004-2007\end{array}$ & & & $\begin{array}{l}0.006^{*} \\
{[0.003]}\end{array}$ & $\begin{array}{r}0.004 \\
{[0.003]}\end{array}$ & & & $\begin{array}{r}0.003 \\
{[0.003]}\end{array}$ & $\begin{array}{r}0.003 \\
{[0.003]}\end{array}$ \\
\hline GDP growth in 2007, WDI & & & $\begin{array}{r}0.007 \\
{[0.016]}\end{array}$ & $\begin{array}{r}0.007 \\
{[0.015]}\end{array}$ & & & $\begin{array}{r}0.005 \\
{[0.014]}\end{array}$ & $\begin{array}{r}0.006 \\
{[0.013]}\end{array}$ \\
\hline CPI inflation in 2007, WDI & & & $\begin{array}{r}0.005 \\
{[0.008]}\end{array}$ & $\begin{array}{r}0.015 \\
{[0.011]}\end{array}$ & & & $\begin{array}{r}0.005 \\
{[0.007]}\end{array}$ & $\begin{array}{r}0.009 \\
{[0.010]}\end{array}$ \\
\hline $\begin{array}{l}\text { Chinn-Ito Index, normalized } \\
\text { in } 2007\end{array}$ & & & & $\begin{array}{r}0.051 \\
{[0.096]}\end{array}$ & & & & $\begin{array}{r}0.065 \\
{[0.097]}\end{array}$ \\
\hline $\begin{array}{l}\text { Standard \& Poor's sovereign } \\
\text { LCU credit rating in } 2007\end{array}$ & & & & $\begin{array}{r}0.016 \\
{[0.012]}\end{array}$ & & & & $\begin{array}{r}0.004 \\
{[0.011]}\end{array}$ \\
\hline Observations & 49 & 48 & 43 & 41 & 49 & 48 & 43 & 41 \\
\hline R-squared & 0.018 & 0.177 & 0.416 & 0.446 & 0.205 & 0.452 & 0.544 & 0.549 \\
\hline
\end{tabular}

$\mathrm{CPI}=$ consumer price index, GDP = gross domestic product, $\mathrm{LBS}=$ locational banking statistics, $\mathrm{LCU}=$ local currency unit, WDI = World Development Indicators.

Notes: The dependent variable is the rate of aggregate capital outflows from each emerging economy after the global financial crisis. Measures of (regional) direct and indirect exposures are calculated using cross-border claims on the banking sector based on locational banking statistics.

The rate of capital outflows is measured using the difference between the maximum and the minimum levels of bilateral foreign claims during the period from the first quarter (Q1) of 2007 to Q3 2008 and the period afterwards, respectively. Measures of direct and indirect exposures are calculated using consolidated banking statistics on immediate counterparty basis. Measures of regional direct and indirect exposures are regional weighted averages using total claims as weights after excluding the country in concern. Average annual percentage change in the real exchange rate is derived by the appreciation rate from the maximum to the minimum values of the real exchange rate where these two extreme values are calculated during January 2003 to December 2007. The real exchange rate is defined as the nominal exchange rate of the domestic currency against the United States (US) dollar deflated by the domestic and the US consumer price indices, respectively. For others, see data description in Appendix Table A1.2. Numbers in brackets are robust standard errors and ${ }^{* * *},{ }^{* *}$, and ${ }^{*}$ denote the significance levels of $1 \%, 5 \%$, and $10 \%$, respectively.

Source: Authors' calculations. 
Table 3 continued

(c) Banking sector claims based on the consolidated banking statistics on ultimate risk basis (bilateral)

\begin{tabular}{|c|c|c|c|c|c|c|c|c|}
\hline Variables & $\begin{array}{c}\text { (1) } \\
\text { Outflow }\end{array}$ & $\begin{array}{c}\text { (2) } \\
\text { Outflow }\end{array}$ & $\begin{array}{l}(3) \\
\text { Outflow }\end{array}$ & $\begin{array}{c}\text { (4) } \\
\text { Outflow }\end{array}$ & $\begin{array}{l}\text { (5) } \\
\text { Outflow }\end{array}$ & $\begin{array}{c}\text { (6) } \\
\text { Outflow }\end{array}$ & $\begin{array}{c}\text { (7) } \\
\text { Outflow }\end{array}$ & $\begin{array}{l}\text { (8) } \\
\text { Outflow }\end{array}$ \\
\hline $\begin{array}{l}\text { Direct exposure of the } \\
\text { banking sector (CBS) in } 2007\end{array}$ & $\begin{array}{r}0.080 \\
{[0.151]}\end{array}$ & $\begin{array}{r}0.192 \\
{[0.181]}\end{array}$ & $\begin{array}{r}0.236 \\
{[0.201]}\end{array}$ & $\begin{array}{r}0.198 \\
{[0.218]}\end{array}$ & $\begin{array}{r}0.228 \\
{[0.157]}\end{array}$ & $\begin{array}{r}0.282 \\
{[0.183]}\end{array}$ & $\begin{array}{r}0.223 \\
{[0.201]}\end{array}$ & $\begin{array}{r}0.180 \\
{[0.220]}\end{array}$ \\
\hline $\begin{array}{l}\text { Regional direct exposure } \\
\text { of the banking sector (CBS) } \\
\text { in } 2007\end{array}$ & & $\begin{array}{l}-0.210 \\
{[0.161]}\end{array}$ & $\begin{array}{l}-0.226 \\
{[0.167]}\end{array}$ & $\begin{array}{r}-0.290^{*} \\
{[0.167]}\end{array}$ & & $\begin{array}{r}-0.121 \\
{[0.173]}\end{array}$ & $\begin{array}{r}-0.127 \\
{[0.178]}\end{array}$ & $\begin{array}{l}-0.209 \\
{[0.184]}\end{array}$ \\
\hline $\begin{array}{l}\text { Indirect exposure of the } \\
\text { banking sector (CBS) in } 2007\end{array}$ & & & & & $\begin{array}{r}2.577^{* * *} \\
{[0.839]}\end{array}$ & $\begin{array}{r}2.438^{* * *} \\
{[0.899]}\end{array}$ & $\begin{array}{r}1.833 \\
{[1.209]}\end{array}$ & $\begin{array}{r}1.452 \\
{[1.312]}\end{array}$ \\
\hline $\begin{array}{l}\text { Regional indirect exposure } \\
\text { of the banking sector (CBS) } \\
\text { in } 2007\end{array}$ & & & & & & $\begin{array}{r}0.060 \\
{[2.665]}\end{array}$ & $\begin{array}{r}1.013 \\
{[2.787]}\end{array}$ & $\begin{array}{r}0.564 \\
{[2.816]}\end{array}$ \\
\hline Dummy of same region & $\begin{array}{r}-0.222^{* * *} \\
{[0.050]}\end{array}$ & $\begin{array}{r}-0.253^{* * *} \\
{[0.058]}\end{array}$ & $\begin{array}{r}-0.261^{1 * *} \\
{[0.057]}\end{array}$ & $\begin{array}{r}-0.261^{* * *} \\
{[0.055]}\end{array}$ & $\begin{array}{r}-0.200^{* * *} \\
{[0.051]}\end{array}$ & $\begin{array}{r}-0.230^{* * *} \\
{[0.060]}\end{array}$ & $\begin{array}{r}-0.257^{* * *} \\
{[0.058]}\end{array}$ & $\begin{array}{r}-0.258^{* * *} \\
{[0.056]}\end{array}$ \\
\hline $\begin{array}{l}\text { Aggravation of current } \\
\text { account balance 2004-2007 }\end{array}$ & & & $\begin{array}{r}-0.002 \\
{[0.004]}\end{array}$ & $\begin{array}{r}-0.001 \\
{[0.004]}\end{array}$ & & & $\begin{array}{r}-0.004 \\
{[0.004]}\end{array}$ & $\begin{array}{r}-0.001 \\
{[0.004]}\end{array}$ \\
\hline $\begin{array}{l}\text { Average annual percentage } \\
\text { change in the real exchange } \\
\text { rate, 2005-2007 }\end{array}$ & & & $\begin{array}{r}0.122 \\
{[0.269]}\end{array}$ & $\begin{array}{r}0.226 \\
{[0.276]}\end{array}$ & & & $\begin{array}{r}0.182 \\
{[0.274]}\end{array}$ & $\begin{array}{r}0.277 \\
{[0.282]}\end{array}$ \\
\hline $\begin{array}{l}\text { Increase in domestic credit, } \\
2004-2007\end{array}$ & & & $\begin{array}{l}0.003^{*} \\
{[0.001]}\end{array}$ & $\begin{array}{r}0.002 \\
{[0.001]}\end{array}$ & & & $\begin{array}{r}0.002 \\
{[0.002]}\end{array}$ & $\begin{array}{r}0.002 \\
{[0.002]}\end{array}$ \\
\hline GDP growth in 2007, WDI & & & $\begin{array}{r}0.002 \\
{[0.006]}\end{array}$ & $\begin{array}{r}0.005 \\
{[0.006]}\end{array}$ & & & $\begin{array}{l}-0.002 \\
{[0.007]}\end{array}$ & $\begin{array}{r}0.002 \\
{[0.007]}\end{array}$ \\
\hline CPI inflation in 2007, WDI & & & $\begin{array}{r}0.005 \\
{[0.005]}\end{array}$ & $\begin{array}{r}0.011^{*} \\
{[0.006]}\end{array}$ & & & $\begin{array}{r}0.004 \\
{[0.005]}\end{array}$ & $\begin{array}{r}0.008 \\
{[0.006]}\end{array}$ \\
\hline $\begin{array}{l}\text { Chinn-Ito Index, normalized } \\
\text { in } 2007\end{array}$ & & & & $\begin{array}{l}0.104^{* *} \\
{[0.051]}\end{array}$ & & & & $\begin{array}{r}0.095^{*} \\
{[0.052]}\end{array}$ \\
\hline $\begin{array}{l}\text { Standard \& Poor's sovereign } \\
\text { LCU credit rating in } 2007\end{array}$ & & & & $\begin{array}{r}0.007 \\
{[0.006]}\end{array}$ & & & & $\begin{array}{r}0.004 \\
{[0.007]}\end{array}$ \\
\hline Observations & 564 & 547 & 498 & 482 & 564 & 547 & 498 & 482 \\
\hline R-squared & 0.030 & 0.032 & 0.060 & 0.078 & 0.044 & 0.043 & 0.065 & 0.081 \\
\hline
\end{tabular}

$\mathrm{CBS}=$ consolidated banking statistics, $\mathrm{CPI}=$ consumer price index, $\mathrm{GDP}=$ gross domestic product, $\mathrm{LCU}=$ local currency unit, $\mathrm{WDI}=\mathrm{World}$ Development Indicators.

Notes: The dependent variable is the rate of bilateral capital outflows from each emerging economy to each reporting country after the global financial crisis. Measures of (regional) direct and indirect exposures are calculated using cross-border claims on the banking sector based on locational banking statistics. Dummy of the same region takes one if the reporting country belongs to the same region as the emerging economy.

The rate of capital outflows is measured using the difference between the maximum and the minimum levels of bilateral foreign claims during the period from the first quarter (Q1) of 2007 to Q3 2008 and the period afterwards, respectively. Measures of direct and indirect exposures are calculated using consolidated banking statistics on immediate counterparty basis. Measures of regional direct and indirect exposures are regional weighted averages using total claims as weights after excluding the country in concern. Average annual percentage change in the real exchange rate is derived by the appreciation rate from the maximum to the minimum values of the real exchange rate where these two extreme values are calculated during January 2003 to December 2007. The real exchange rate is defined as the nominal exchange rate of the domestic currency against the United States (US) dollar deflated by the domestic and the US consumer price indices, respectively. For others, see data description in Appendix Table A1.2. Numbers in brackets are robust standard errors and ${ }^{* * *}$, **, and ${ }^{*}$ denote the significance levels of $1 \%, 5 \%$, and $10 \%$, respectively.

Source: Authors' calculations. 
Table 3 continued

(d) Banking sector claims based on the locational banking statistics (bilateral)

\begin{tabular}{|c|c|c|c|c|c|c|c|c|}
\hline Variables & $\begin{array}{c}\text { (1) } \\
\text { Outflow }\end{array}$ & $\begin{array}{c}\text { (2) } \\
\text { Outflow }\end{array}$ & $\begin{array}{c}\text { (3) } \\
\text { Outflow }\end{array}$ & $\begin{array}{c}\text { (4) } \\
\text { Outflow }\end{array}$ & $\begin{array}{l}(5) \\
\text { Outflow }\end{array}$ & $\begin{array}{l}(6) \\
\text { Outflow }\end{array}$ & $\begin{array}{c}\text { (7) } \\
\text { Outflow }\end{array}$ & $\begin{array}{l}\text { (8) } \\
\text { Outflow }\end{array}$ \\
\hline $\begin{array}{l}\text { Direct exposure of the } \\
\text { banking sector (LBS) } \\
\text { in } 2007\end{array}$ & $\begin{array}{r}0.052 \\
{[0.055]}\end{array}$ & $\begin{array}{r}-0.010 \\
{[0.057]}\end{array}$ & $\begin{array}{r}-0.062 \\
{[0.060]}\end{array}$ & $\begin{array}{r}-0.071 \\
{[0.071]}\end{array}$ & $\begin{array}{r}0.058 \\
{[0.055]}\end{array}$ & $\begin{array}{r}-0.017 \\
{[0.061]}\end{array}$ & $\begin{array}{l}-0.037 \\
{[0.067]}\end{array}$ & $\begin{array}{l}-0.048 \\
{[0.077]}\end{array}$ \\
\hline $\begin{array}{l}\text { Regional direct exposure } \\
\text { of the banking sector (LBS) } \\
\text { in } 2007\end{array}$ & & $\begin{array}{r}0.541^{* * *} \\
{[0.147]}\end{array}$ & $\begin{array}{l}0.334^{* *} \\
{[0.169]}\end{array}$ & $\begin{array}{c}0.379^{*} \\
{[0.199]}\end{array}$ & & $\begin{array}{r}0.429^{* * *} \\
{[0.159]}\end{array}$ & $\begin{array}{l}0.305^{*} \\
{[0.175]}\end{array}$ & $\begin{array}{r}0.341 \\
{[0.208]}\end{array}$ \\
\hline $\begin{array}{l}\text { Indirect exposure of the } \\
\text { Banking Sector (LBS) } \\
\text { in } 2007\end{array}$ & & & & & $\begin{array}{r}0.352^{* * *} \\
{[0.136]}\end{array}$ & $\begin{array}{r}0.150 \\
{[0.164]}\end{array}$ & $\begin{array}{r}0.249 \\
{[0.193]}\end{array}$ & $\begin{array}{r}0.234 \\
{[0.198]}\end{array}$ \\
\hline $\begin{array}{l}\text { Regional indirect exposure } \\
\text { of the Banking Sector (LBS) } \\
\text { in } 2007\end{array}$ & & & & & & $\begin{array}{r}0.423^{*} \\
{[0.243]}\end{array}$ & $\begin{array}{l}-0.099 \\
{[0.320]}\end{array}$ & $\begin{array}{l}-0.082 \\
{[0.360]}\end{array}$ \\
\hline Dummy of same region & $\begin{array}{l}-0.071^{*} \\
{[0.038]}\end{array}$ & $\begin{array}{r}0.017 \\
{[0.040]}\end{array}$ & $\begin{array}{r}-0.015 \\
{[0.046]}\end{array}$ & $\begin{array}{r}-0.017 \\
{[0.046]}\end{array}$ & $\begin{array}{l}-0.064 \\
{[0.039]}\end{array}$ & $\begin{array}{r}0.020 \\
{[0.042]}\end{array}$ & $\begin{array}{r}-0.015 \\
{[0.047]}\end{array}$ & $\begin{array}{r}-0.017 \\
{[0.047]}\end{array}$ \\
\hline $\begin{array}{l}\text { Aggravation of current } \\
\text { account balance 2004- } \\
2007\end{array}$ & & & $\begin{array}{r}-0.001 \\
{[0.003]}\end{array}$ & $\begin{array}{r}-0.001 \\
{[0.003]}\end{array}$ & & & $\begin{array}{r}0.001 \\
{[0.003]}\end{array}$ & $\begin{array}{r}0.001 \\
{[0.003]}\end{array}$ \\
\hline $\begin{array}{l}\text { Average annual percentage } \\
\text { change in the real exchange } \\
\text { rate, 2005-2007 }\end{array}$ & & & $\begin{array}{r}0.127 \\
{[0.219]}\end{array}$ & $\begin{array}{r}0.185 \\
{[0.222]}\end{array}$ & & & $\begin{array}{r}0.158 \\
{[0.219]}\end{array}$ & $\begin{array}{r}0.208 \\
{[0.224]}\end{array}$ \\
\hline $\begin{array}{l}\text { Increase in domestic credit, } \\
2004-2007\end{array}$ & & & $\begin{array}{r}0.004^{* * *} \\
{[0.001]}\end{array}$ & $\begin{array}{r}0.004^{* * *} \\
{[0.001]}\end{array}$ & & & $\begin{array}{r}0.004^{* * *} \\
{[0.001]}\end{array}$ & $\begin{array}{r}0.004^{* * *} \\
{[0.001]}\end{array}$ \\
\hline GDP growth in 2007, WDI & & & $\begin{array}{r}0.002 \\
{[0.005]}\end{array}$ & $\begin{array}{r}0.003 \\
{[0.005]}\end{array}$ & & & $\begin{array}{r}0.004 \\
{[0.005]}\end{array}$ & $\begin{array}{r}0.004 \\
{[0.005]}\end{array}$ \\
\hline CPI inflation in 2007, WDI & & & $\begin{array}{r}0.000 \\
{[0.004]}\end{array}$ & $\begin{array}{r}0.001 \\
{[0.005]}\end{array}$ & & & $\begin{array}{r}0.001 \\
{[0.004]}\end{array}$ & $\begin{array}{r}0.001 \\
{[0.005]}\end{array}$ \\
\hline $\begin{array}{l}\text { Chinn-Ito Index, normalized } \\
\text { in } 2007\end{array}$ & & & & $\begin{array}{r}-0.003 \\
{[0.042]}\end{array}$ & & & & $\begin{array}{l}-0.000 \\
{[0.042]}\end{array}$ \\
\hline $\begin{array}{l}\text { Standard \& Poor's sovereign } \\
\text { LCU credit rating in } 2007\end{array}$ & & & & $\begin{array}{l}-0.000 \\
{[0.005]}\end{array}$ & & & & $\begin{array}{l}-0.000 \\
{[0.006]}\end{array}$ \\
\hline Observations & 850 & 828 & 736 & 707 & 850 & 828 & 736 & 707 \\
\hline R-squared & 0.006 & 0.020 & 0.044 & 0.046 & 0.014 & 0.027 & 0.047 & 0.048 \\
\hline
\end{tabular}

$\mathrm{CPI}=$ consumer price index, GDP = gross domestic product, $\mathrm{LBS}=$ locational banking statistics, $\mathrm{LCU}=$ local currency unit, WDI = World Development Indicators.

Notes: The dependent variable is the rate of bilateral capital outflows from each emerging economy to each reporting country after the global financial crisis. Measures of (regional) direct and indirect exposures are calculated using cross-border claims on the banking sector based on locational banking statistics. Dummy of the same region takes one if the reporting country belongs to the same region as the emerging economy.

The rate of capital outflows is measured using the difference between the maximum and the minimum levels of bilateral foreign claims during the period from the first quarter (Q1) of 2007 to Q3 2008 and the period afterwards, respectively. Measures of direct and indirect exposures are calculated using consolidated banking statistics on immediate counterparty basis. Measures of regional direct and indirect exposures are regional weighted averages using total claims as weights after excluding the country in concern. Average annual percentage change in the real exchange rate is derived by the appreciation rate from the maximum to the minimum values of the real exchange rate where these two extreme values are calculated during January 2003 to December 2007. The real exchange rate is defined as the nominal exchange rate of the domestic currency against the United States (US) dollar deflated by the domestic and the US consumer price indices, respectively. For others, see data description in Appendix Table A1.2. Numbers in brackets are robust standard errors and ${ }^{* * *},{ }^{* *}$, and ${ }^{*}$ denote the significance levels of $1 \%, 5 \%$, and $10 \%$, respectively.

Source: Authors' calculations. 


\section{Table 4: Contagion Effects in Capital Outflows Due to Exposures of Short-Term Claims: The Consolidated Banking Statistics on Immediate Counterparty Basis}

(a) Aggregate

\begin{tabular}{|c|c|c|c|c|c|c|c|c|}
\hline Variables & $\begin{array}{c}(1) \\
\text { Outflow }\end{array}$ & $\begin{array}{c}\text { (2) } \\
\text { Outflow }\end{array}$ & $\begin{array}{l}\text { (3) } \\
\text { Outflow }\end{array}$ & $\begin{array}{c}\text { (4) } \\
\text { Outflow }\end{array}$ & $\begin{array}{l}\text { (5) } \\
\text { Outflow }\end{array}$ & $\begin{array}{c}(6) \\
\text { Outflow }\end{array}$ & $\begin{array}{c}\text { (7) } \\
\text { Outflow }\end{array}$ & $\begin{array}{l}\text { (8) } \\
\text { Outflow }\end{array}$ \\
\hline $\begin{array}{l}\text { Direct exposure of short- } \\
\text { term debts (CBS) in } 2007\end{array}$ & $\begin{array}{c}0.571^{*} \\
{[0.331]}\end{array}$ & $\begin{array}{r}0.308 \\
{[0.362]}\end{array}$ & $\begin{array}{r}0.495 \\
{[0.328]}\end{array}$ & $\begin{array}{r}0.453 \\
{[0.364]}\end{array}$ & $\begin{array}{r}0.611^{*} \\
{[0.313]}\end{array}$ & $\begin{array}{r}0.359 \\
{[0.348]}\end{array}$ & $\begin{array}{r}0.500 \\
{[0.308]}\end{array}$ & $\begin{array}{r}0.440 \\
{[0.347]}\end{array}$ \\
\hline $\begin{array}{l}\text { Regional direct exposure } \\
\text { of short-term debts (CBS) } \\
\text { in } 2007\end{array}$ & & $\begin{array}{r}1.093^{*} \\
{[0.568]}\end{array}$ & $\begin{array}{r}0.307 \\
{[0.675]}\end{array}$ & $\begin{array}{r}0.610 \\
{[0.804]}\end{array}$ & & $\begin{array}{r}1.048^{*} \\
{[0.560]}\end{array}$ & $\begin{array}{r}0.353 \\
{[0.691]}\end{array}$ & $\begin{array}{r}0.639 \\
{[0.862]}\end{array}$ \\
\hline $\begin{array}{l}\text { Indirect exposure of short- } \\
\text { term debts (CBS) in } 2007\end{array}$ & & & & & $\begin{array}{r}-1.954 \\
{[1.798]}\end{array}$ & $\begin{array}{r}-1.995 \\
{[1.849]}\end{array}$ & $\begin{array}{r}-1.856 \\
{[2.526]}\end{array}$ & $\begin{array}{l}-2.075 \\
{[2.761]}\end{array}$ \\
\hline $\begin{array}{l}\text { Regional indirect exposure } \\
\text { of short-term debts (CBS) } \\
\text { in } 2007\end{array}$ & & & & & & $\begin{array}{r}0.447 \\
{[4.541]}\end{array}$ & $\begin{array}{l}-0.252 \\
{[3.652]}\end{array}$ & $\begin{array}{r}0.558 \\
{[3.738]}\end{array}$ \\
\hline $\begin{array}{l}\text { Aggravation of current } \\
\text { account balance } \\
\text { 2004-2007 }\end{array}$ & & & $\begin{array}{r}-0.008 \\
{[0.009]}\end{array}$ & $\begin{array}{r}-0.008 \\
{[0.008]}\end{array}$ & & & $\begin{array}{r}-0.008 \\
{[0.009]}\end{array}$ & $\begin{array}{r}-0.008 \\
{[0.008]}\end{array}$ \\
\hline $\begin{array}{l}\text { Average annual percentage } \\
\text { change in the real exchange } \\
\text { rate, 2005-2007 }\end{array}$ & & & $\begin{array}{r}-0.358 \\
{[0.620]}\end{array}$ & $\begin{array}{r}-0.328 \\
{[0.569]}\end{array}$ & & & $\begin{array}{r}-0.239 \\
{[0.593]}\end{array}$ & $\begin{array}{l}-0.230 \\
{[0.569]}\end{array}$ \\
\hline $\begin{array}{l}\text { Increase in domestic credit, } \\
\text { 2004-2007 }\end{array}$ & & & $\begin{array}{r}0.006^{*} \\
{[0.003]}\end{array}$ & $\begin{array}{r}0.007^{*} \\
{[0.004]}\end{array}$ & & & $\begin{array}{r}0.006^{*} \\
{[0.003]}\end{array}$ & $\begin{array}{r}0.006 \\
{[0.004]}\end{array}$ \\
\hline GDP growth in 2007, WDI & & & $\begin{array}{l}-0.007 \\
{[0.013]}\end{array}$ & $\begin{array}{l}-0.006 \\
{[0.014]}\end{array}$ & & & $\begin{array}{l}-0.007 \\
{[0.014]}\end{array}$ & $\begin{array}{l}-0.007 \\
{[0.015]}\end{array}$ \\
\hline CPI inflation in 2007, WDI & & & $\begin{array}{r}-0.011 \\
{[0.011]}\end{array}$ & $\begin{array}{r}-0.017 \\
{[0.014]}\end{array}$ & & & $\begin{array}{l}-0.006 \\
{[0.015]}\end{array}$ & $\begin{array}{r}-0.012 \\
{[0.018]}\end{array}$ \\
\hline $\begin{array}{l}\text { Chinn-Ito Index, normalized } \\
\text { in } 2007\end{array}$ & & & & $\begin{array}{l}-0.098 \\
{[0.154]}\end{array}$ & & & & $\begin{array}{l}-0.098 \\
{[0.169]}\end{array}$ \\
\hline $\begin{array}{l}\text { Standard \& Poor's sovereign } \\
\text { LCU credit rating in } 2007\end{array}$ & & & & $\begin{array}{r}-0.012 \\
{[0.016]}\end{array}$ & & & & $\begin{array}{r}-0.014 \\
{[0.017]}\end{array}$ \\
\hline Observations & 49 & 48 & 43 & 41 & 49 & 48 & 43 & 41 \\
\hline R-squared & 0.068 & 0.124 & 0.263 & 0.291 & 0.083 & 0.140 & 0.273 & 0.304 \\
\hline
\end{tabular}

$\mathrm{CBS}=$ consolidated banking statistics, $\mathrm{CPI}=$ consumer price index, GDP = gross domestic product, $\mathrm{LCU}=$ local currency unit, WDI = World Development Indicators.

Notes: The dependent variable is the rate of aggregate capital outflows from each emerging economy after the global financial crisis.

Measures of (regional) direct and indirect exposures are calculated using short-term international borrowings based on consolidated banking statistics on immediate counterparty basis.

The rate of capital outflows is measured using the difference between the maximum and the minimum levels of bilateral foreign claims during the period from the first quarter (Q1) of 2007 to Q3 2008 and the period afterwards, respectively. Measures of direct and indirect exposures are calculated using consolidated banking statistics on immediate counterparty basis. Measures of regional direct and indirect exposures are regional weighted averages using total claims as weights after excluding the country in concern. Average annual percentage change in the real exchange rate is derived by the appreciation rate from the maximum to the minimum values of the real exchange rate where these two extreme values are calculated during January 2003 to December 2007. The real exchange rate is defined as the nominal exchange rate of the domestic currency against the United States (US) dollar deflated by the domestic and the US consumer price indices, respectively. For others, see data description in Appendix Table A1.2. Numbers in brackets are robust standard errors and ${ }^{* * *}$, ${ }^{* *}$, and ${ }^{*}$ denote the significance levels of $1 \%, 5 \%$, and $10 \%$, respectively.

Source: Authors' calculations. 
Table 4 continued

(b) Bilateral

\begin{tabular}{|c|c|c|c|c|c|c|c|c|}
\hline Variables & $\begin{array}{c}\text { (1) } \\
\text { Outflow }\end{array}$ & $\begin{array}{l}\text { (2) } \\
\text { Outflow }\end{array}$ & $\begin{array}{c}\text { (3) } \\
\text { Outflow }\end{array}$ & $\begin{array}{c}\text { (4) } \\
\text { Outflow }\end{array}$ & $\begin{array}{c}\text { (5) } \\
\text { Outflow }\end{array}$ & $\begin{array}{c}(6) \\
\text { Outflow }\end{array}$ & $\begin{array}{c}\text { (7) } \\
\text { Outflow }\end{array}$ & $\begin{array}{c}(8) \\
\text { Outflow }\end{array}$ \\
\hline $\begin{array}{l}\text { Direct exposure of short- } \\
\text { term debts (CBS) in } 2007\end{array}$ & $\begin{array}{r}0.027 \\
{[0.112]}\end{array}$ & $\begin{array}{r}-0.009 \\
{[0.131]}\end{array}$ & $\begin{array}{r}0.050 \\
{[0.139]}\end{array}$ & $\begin{array}{r}0.086 \\
{[0.134]}\end{array}$ & $\begin{array}{r}0.025 \\
{[0.112]}\end{array}$ & $\begin{array}{l}-0.014 \\
{[0.131]}\end{array}$ & $\begin{array}{r}0.034 \\
{[0.138]}\end{array}$ & $\begin{array}{r}0.065 \\
{[0.133]}\end{array}$ \\
\hline $\begin{array}{l}\text { Regional direct exposure } \\
\text { of short-term debts (CBS) } \\
\text { in } 2007\end{array}$ & & $\begin{array}{r}0.099 \\
{[0.259]}\end{array}$ & $\begin{array}{r}-0.183 \\
{[0.301]}\end{array}$ & $\begin{array}{r}-0.410 \\
{[0.309]}\end{array}$ & & $\begin{array}{r}0.076 \\
{[0.267]}\end{array}$ & $\begin{array}{r}-0.210 \\
{[0.309]}\end{array}$ & $\begin{array}{l}-0.488 \\
{[0.321]}\end{array}$ \\
\hline $\begin{array}{l}\text { Indirect exposure of short- } \\
\text { term debts (CBS) in } 2007\end{array}$ & & & & & $\begin{array}{r}0.188 \\
{[0.935]}\end{array}$ & $\begin{array}{r}0.136 \\
{[0.941]}\end{array}$ & $\begin{array}{r}-0.999 \\
{[1.150]}\end{array}$ & $\begin{array}{l}-0.103 \\
{[1.130]}\end{array}$ \\
\hline $\begin{array}{l}\text { Regional indirect exposure } \\
\text { of short-term debts (CBS) } \\
\text { in } 2007\end{array}$ & & & & & & $\begin{array}{r}0.930 \\
{[1.403]}\end{array}$ & $\begin{array}{r}0.993 \\
{[1.527]}\end{array}$ & $\begin{array}{r}2.011 \\
{[1.610]}\end{array}$ \\
\hline Dummy of same region & $\begin{array}{r}-0.224^{* * *} \\
{[0.050]}\end{array}$ & $\begin{array}{r}-0.250^{* * *} \\
{[0.059]}\end{array}$ & $\begin{array}{r}-0.269^{* * *} \\
{[0.059]}\end{array}$ & $\begin{array}{r}-0.271^{* * *} \\
{[0.057]}\end{array}$ & $\begin{array}{r}-0.222^{* * *} \\
{[0.051]}\end{array}$ & $\begin{array}{r}-0.244^{* * *} \\
{[0.061]}\end{array}$ & $\begin{array}{r}-0.272^{* * *} \\
{[0.060]}\end{array}$ & $\begin{array}{r}-0.265^{* * *} \\
{[0.059]}\end{array}$ \\
\hline $\begin{array}{l}\text { Aggravation of current } \\
\text { account balance 2004-2007 }\end{array}$ & & & $\begin{array}{l}-0.003 \\
{[0.004]}\end{array}$ & $\begin{array}{r}-0.001 \\
{[0.004]}\end{array}$ & & & $\begin{array}{l}-0.004 \\
{[0.004]}\end{array}$ & $\begin{array}{r}-0.001 \\
{[0.004]}\end{array}$ \\
\hline $\begin{array}{l}\text { Average annual percentage } \\
\text { change in the real exchange } \\
\text { rate, 2005-2007 }\end{array}$ & & & $\begin{array}{r}0.156 \\
{[0.268]}\end{array}$ & $\begin{array}{r}0.254 \\
{[0.269]}\end{array}$ & & & $\begin{array}{r}0.177 \\
{[0.273]}\end{array}$ & $\begin{array}{r}0.230 \\
{[0.275]}\end{array}$ \\
\hline $\begin{array}{l}\text { Increase in domestic credit, } \\
2004-2007\end{array}$ & & & $\begin{array}{r}0.002^{*} \\
{[0.001]}\end{array}$ & $\begin{array}{r}0.003^{*} \\
{[0.002]}\end{array}$ & & & $\begin{array}{r}0.002 \\
{[0.001]}\end{array}$ & $\begin{array}{r}0.003^{*} \\
{[0.002]}\end{array}$ \\
\hline GDP growth in 2007, WDI & & & $\begin{array}{r}0.001 \\
{[0.007]}\end{array}$ & $\begin{array}{r}0.004 \\
{[0.006]}\end{array}$ & & & $\begin{array}{r}0.000 \\
{[0.007]}\end{array}$ & $\begin{array}{r}0.003 \\
{[0.006]}\end{array}$ \\
\hline CPI inflation in 2007, WDI & & & $\begin{array}{r}0.006 \\
{[0.005]}\end{array}$ & $\begin{array}{r}0.011^{*} \\
{[0.006]}\end{array}$ & & & $\begin{array}{r}0.009 \\
{[0.005]}\end{array}$ & $\begin{array}{r}0.010 \\
{[0.006]}\end{array}$ \\
\hline $\begin{array}{l}\text { Chinn-Ito Index, normalized } \\
\text { in } 2007\end{array}$ & & & & $\begin{array}{l}0.120^{* *} \\
{[0.047]}\end{array}$ & & & & $\begin{array}{l}0.138^{* * *} \\
{[0.049]}\end{array}$ \\
\hline $\begin{array}{l}\text { Standard \& Poor's sovereign } \\
\text { LCU credit rating in } 2007\end{array}$ & & & & $\begin{array}{r}0.006 \\
{[0.006]}\end{array}$ & & & & $\begin{array}{r}0.004 \\
{[0.007]}\end{array}$ \\
\hline Observations & 571 & 554 & 498 & 482 & 571 & 554 & 498 & 482 \\
\hline R-squared & 0.030 & 0.029 & 0.058 & 0.077 & 0.030 & 0.030 & 0.060 & 0.080 \\
\hline
\end{tabular}

$\mathrm{CBS}=$ consolidated banking statistics, $\mathrm{CPI}=$ consumer price index, $\mathrm{GDP}=$ gross domestic product, $\mathrm{LCU}=$ local currency unit, WDI = World Development Indicators.

Notes: The dependent variable is the rate of bilateral capital outflows from each emerging economy to each reporting country after the global financial crisis. Measures of (regional) direct and indirect exposures are calculated using short-term international borrowings based on consolidated banking statistics on immediate counterparty basis. Dummy of the same region takes one if the reporting country belongs to the same region as the emerging economy.

The rate of capital outflows is measured using the difference between the maximum and the minimum levels of bilateral foreign claims during the period from the first quarter (Q1) of 2007 to Q3 2008 and the period afterwards, respectively. Measures of direct and indirect exposures are calculated using consolidated banking statistics on immediate counterparty basis. Measures of regional direct and indirect exposures are regional weighted averages using total claims as weights after excluding the country in concern. Average annual percentage change in the real exchange rate is derived by the appreciation rate from the maximum to the minimum values of the real exchange rate where these two extreme values are calculated during January 2003 to December 2007. The real exchange rate is defined as the nominal exchange rate of the domestic currency against the United States (US) dollar deflated by the domestic and the US consumer price indices, respectively. For others, see data description in Appendix Table A1.2. Numbers in brackets are robust standard errors and ${ }^{* * *},{ }^{* *}$, and ${ }^{*}$ denote the significance levels of $1 \%, 5 \%$, and $10 \%$, respectively.

Source: Authors' calculations. 


\section{CONCLUSION}

An increasing number of studies have noted the collapse of cross-border lending by foreign banks after the global financial crisis as a major transmission channel of financial (liquidity) crisis. The network of cross-border banking appears to play an important role in financial contagion and how shocks are transmitted across borders. Especially in times of crisis, information asymmetry becomes an acute issue, which makes economic proximity an added consideration when banks decide on appropriate risk exposures. For example, given heightened uncertainty, international banks may withdraw lending from an economy regardless of its own risk exposures if it belongs to a region whose overall exposure is high. On the other hand, the lender may retrench less from an emerging economy if the emerging economy is in the same region as the lender provided that the lender has more information and/or business relationship with this emerging economy based on geographic proximity.

This paper investigated and tested the role of regional exposures in financial contagion from advanced to EMEs through the global banking network. First, we examined whether the economy can become more susceptible to capital outflows, regardless of its own bank exposures, if other economies in the same region are heavily exposed to crisis countries. Second, we tested whether the same region lender tend to reduce their exposures to the emerging market borrowers less relative to different regional lenders during crisis.

Using bilateral data from BIS international banking statistics, we found supporting evidence for both hypotheses. First, we found that the direct exposures of the country's own and the overall region's banking sectors to crisis-affected countries are systematically related to bank capital outflows during the global financial crisis. In some specifications, we found that indirect regional exposures were also positive and statistically significant, indicating contagion effects at the regional level more deeply rooted in the global financial network. Second, we also find that the same region lender exhibits more favorable behavior toward emerging economies during the crisis. That is, when lenders and borrowers belong to the same region, the lenders are less likely to retreat from the same region borrowers at the time of financial stress. Using the LBS presents more consistent and stronger evidence of contagion effects at the regional level. However, the effect of the same region dummy seems to be weaker with the LBS.

A number of policy implications emerge from our analysis. First, cross-border banking networks are key channels of transmission of financial crises. Growing financial globalization exposes emerging countries to greater capital flow volatility and market instability. While it is important for each nation to continue implementing sound macroeconomic policies, supported by independent central banks and prudent fiscal management, crises highlight the region's common vulnerabilities and the need for effective coordination across national and international institutions to safeguard financial stability.

Second, regional economic and financial cooperation should continue to serve as a counterweight to the vagaries of financial globalization. Given the spillover effects of regional exposures, the region needs to deepen its financial sector cooperation by supporting the region's financial regulators and policy makers to come together to deliberate on common frameworks in banking supervision and avoid potential contagion. They can also promote common approaches for addressing the region's common financial stability challenges by sharing cross-country experience on the use of countercyclical and macroprudential policies. 
Third, greater regional cooperation is needed to reinforce regional financial safety nets and their links to the global safety net arrangement. Financial crises are becoming more frequent and costly in an increasing global network of finance. To enhance financial stability and resilience, the region should strengthen the regional mechanism for liquidity support and crisis management (the Chiang Mai Initiative Multilateralization) and its economic surveillance through the ASEAN+3 Macroeconomic Research Office, while continuing efforts to develop domestic capital marketsespecially local currency bond markets-to enhance financial resilience. 


\section{APPENDIX}

\section{Table A1.1: Reporting Economies and Counterparty Emerging Market Economies by Region}

\begin{tabular}{|c|c|c|}
\hline Region & Reporting Economies & Counterparty Emerging Economies \\
\hline East Asia & $\begin{array}{l}\text { Taipei,China; Hong Kong, China, Japan; } \\
\text { Macau, China; Republic of Korea }\end{array}$ & $\begin{array}{l}\text { Bangladesh, India, Indonesia, Malaysia, } \\
\text { Mongolia, Pakistan, Philippines, Republic of } \\
\text { Korea, Sri Lanka, Thailand }\end{array}$ \\
\hline Other Asia & & $\begin{array}{l}\text { Armenia, Georgia, Kazakhstan, Kyrgyz } \\
\text { Republic }\end{array}$ \\
\hline Western Europe & $\begin{array}{l}\text { Austria, Belgium, Denmark, Finland, France, } \\
\text { Germany, Greece, Ireland, Luxembourg, } \\
\text { the Netherlands, Spain, Switzerland, United } \\
\text { Kingdom }\end{array}$ & Turkey \\
\hline East Europe & & $\begin{array}{l}\text { Albania, Bosnia and Herzegovina, Bulgaria, } \\
\text { Croatia, Czech Republic, Hungary, Latvia, } \\
\text { Lithuania, Macedonia FYR, Moldova, } \\
\text { Poland, Romania, Russian Federation, } \\
\text { Ukraine }\end{array}$ \\
\hline North America & Canada, United States & \\
\hline Central and South America & Brazil, Chile, Mexico & $\begin{array}{l}\text { Argentina, Brazil, Chile, Colombia, Costa } \\
\text { Rica, Dominican Republic, Guatemala, } \\
\text { Honduras, Jamaica, Mexico, Nicaragua, } \\
\text { Paraguay, Peru, Suriname, Uruguay, } \\
\text { Venezuela }\end{array}$ \\
\hline Africa & South Africa & $\begin{array}{l}\text { Cape Verde, Egypt, Ghana, Kenya, Lesotho, } \\
\text { Mauritius, Morocco, Mozambique, Nigeria, } \\
\text { Seychelles, South Africa, Tanzania, Tunisia, } \\
\text { Uganda }\end{array}$ \\
\hline Middle East & & Israel, Jordan, Lebanon \\
\hline Oceania & Australia & \\
\hline
\end{tabular}

FYR = former Yugoslav Republic.

Sources: Bank for International Settlements, authors' compilation. 


\section{Table A1.2: Definitions of Variables and Data Sources}

\begin{tabular}{|c|c|c|}
\hline Variables & Description and Construction & Data Source \\
\hline Bilateral foreign claims & $\begin{array}{l}\text { Consolidated banking statistics and } \\
\text { locational banking statistics }\end{array}$ & $\begin{array}{l}\text { Bank for International Settlements. } \\
\text { https://www.bis.org (accessed July 2016) }\end{array}$ \\
\hline $\begin{array}{l}\text { GDP growth rate for emerging } \\
\text { countries }\end{array}$ & $\begin{array}{l}\text { GDP in nominal United States (US) } \\
\text { dollars. For countries with missing } \\
\text { quarterly GDP, we use interpolated } \\
\text { annual data. } \\
\text { Aggregate, year-on-year growth rate }\end{array}$ & $\begin{array}{l}\text { International Monetary Fund (IMF). } \\
\text { International Financial Statistics. } \\
\text { www.imf.org/en/Data (accessed September } \\
\text { 2016); World Bank. World Development } \\
\text { Indicators. http://databank.worldbank.org } \\
\text { (accessed October 2016) }\end{array}$ \\
\hline $\begin{array}{l}\text { Percent change in real } \\
\text { exchange rate }\end{array}$ & $\begin{array}{l}\text { Log difference in real exchange rate } \\
\text { (national currency per US dollar) between } \\
\text { January } 2003 \text { to December } 2007\end{array}$ & $\begin{array}{l}\text { IMF. International Financial Statistics. } \\
\text { www.imf.org/en/Data (accessed September } \\
\text { 2016) }\end{array}$ \\
\hline $\begin{array}{l}\text { Increase in current account } \\
\text { deficit from } \\
2010 \text { to } 2012\end{array}$ & $\begin{array}{l}\text { Difference in current account deficit } \\
\text { from } 2004 \text { to } 2007\end{array}$ & $\begin{array}{l}\text { World Bank. World Development Indicators. } \\
\text { http://databank.worldbank.org (accessed } \\
\text { October 2016) }\end{array}$ \\
\hline $\begin{array}{l}\text { Increase in credit to GDP } \\
\text { from } 2004 \text { to } 2007\end{array}$ & $\begin{array}{l}\text { Increase in domestic credit to private } \\
\text { sector (\% of GDP) from } 2004 \text { to } 2007\end{array}$ & \\
\hline $\begin{array}{l}\text { Inflation (consumer price } \\
\text { index) } 2007\end{array}$ & Inflation, consumer prices ( $\%$ annual) & \\
\hline Chinn-Ito Index, 2007 & $\begin{array}{l}\text { An index measuring a country's degree of } \\
\text { capital account openness. It is based on } \\
\text { the binary dummy variables that codify } \\
\text { the tabulation of restrictions on cross- } \\
\text { border financial transactions reported in } \\
\text { the IMF's Annual Report on Exchange } \\
\text { Arrangements and Exchange Restrictions }\end{array}$ & Chinn and Ito (2006) \\
\hline $\begin{array}{l}\text { Standard \& Poor's sovereign } \\
\text { local currency credit rating, } \\
2007\end{array}$ & $\begin{array}{l}\text { End of period credit rating on } \\
\text { government-issued local currency- } \\
\text { denominated debt securities }\end{array}$ & $\begin{array}{l}\text { Standard \& Poor's. Ratings Direct. } \\
\text { https://www.globalcreditportal.com/ratingsdirect } \\
\text { (accessed February 2017) }\end{array}$ \\
\hline
\end{tabular}

Source: Authors' compilation. 


\section{REFERENCES}

Acemoglu, Daron, Asuman Ozdaglar, and Alireza Tahbaz-Salehi. 2015. "Systemic Risk and Stability in Financial Networks." American Economic Review 105 (2): 564-608.

Allen, Franklin, and Ana Babus. 2009. "Networks in Finance." In Network-Based Strategies and Competencies, edited by Paul Kleindorfer and Jerry Wind, 367-82. Philadelphia: Wharton School Publishing.

Asian Development Bank (ADB). 2017. "The Era of Financial Interconnectedness: How Can Asia Strengthen Financial Resilience." Asian Economic Integration Report. Manila.

Avdjiev, Stefan, Patrick McGuire, and Philip Wooldridge. 2015. "Enhanced Data to Analyse International Banking." BIS Quarterly Review, September, 53-68.

Bank for International Settlements (BIS). 2012. Guidelines to the International Locational Banking Statistics. Basel.

2013. Guidelines for Reporting the BIS International Banking Statistics. Basel.

2015. Enhanced Data to Analyse International Banking. Basel.

2016. BIS Statistical Bulletin. Basel.

Bernardini, Marco, and Lorenzo Forni. 2017. "Private and Public Debt: Are Emerging Markets at Risk?” IMF Working Paper No. WP/17/61.

Bruno, Valentina, and Hyun Song Shin. 2015. "Cross-Border Banking and Global Liquidity." Review of Economic Studies 82 (2): 535-64.

Cerutti, Eugenio, Stijn Claessens, and Damien Puy. 2015. "Push Factors and Capital Flows to Emerging Markets: Why Knowing Your Lender Matters More Than Fundamentals." IMF Working Paper No. 15-127.

Cerutti, Eugenio, Stijn Claessens, and Lev Ratnovski. 2017. "Global Liquidity and Cross-Border Bank Flows." Economic Policy 32 (89): 81-125.

Cerutti, Eugenio, Galina Hale, and Camelia Minoiu. 2015. "Financial Crises and the Composition of Cross-Border Lending." Journal of International Money and Finance 52: 60-81.

Chinn, Menzie D., and Hiro Ito. 2006. "What Matters for Financial Development? Capital Controls, Institutions, and Interactions." Journal of Development Economics 81 (1): 163-92. The longer version is available as NBER Working Paper No. 11370. (May 2005). The previous version is "Capital Account Liberalization, Institutions and Financial Development: Cross Country Evidence." (with Menzie Chinn) NBER Working Paper No. 8967 (June 2002).

Choi, Sangyup, and Davide Furceri. 2018. "Uncertainty and Cross-Border Banking Flows." IMF Working Paper No. WP/18/4. 
Claessens, Stijn, and Kristin Forbs. 2004. "International Financial Contagion: The Theory, Evidence and Policy Implications." Paper prepared for The IMF's Role in Emerging Market Economies: Reassessing the Adequacy of Its Resources. Amsterdam. November.

De Haas, Ralph, and Neeltje Van Horen. 2013. "Running for the Exit: International Bank Lending During a Crisis." Review of Financial Studies 26 (1): 244-85.

Eichengreen, Barry, and Poonam Gupta. 2015. "Tapering Talk: The Impact of Expectations of Reduced Federal Reserve Security Purchases on Emerging Markets." Emerging Markets Review 25 (December): 1-15.

Hahm, Joon-Ho, Hyun Song Shin, and Kwanho Shin. 2013. "Non-Core Bank Liabilities and Financial Vulnerability." Journal of Money, Credit and Banking 45 (s1): 3-36.

Hale, Galina, Tümer Kapan, and Camelia Minoiu. 2016. "Crisis Transmission in the Global Banking Network." IMF Working Paper No. 16-91.

Kalemli-Ozcan, Sebnem, Elias Papaioannou, and José Luis Peydró. 2013. "Financial Regulation, Financial Globalization, and the Synchronization of Economic Activity." Journal of Finance 68 (3): 1179-228.

Kaminsky, Graciela L., Carmen M. Reinhart, and Carlos A. Végh. 2004. "When it Rains, It Pours: Procyclical Capital Flows and Macroeconomic Policies.” NBER Macroeconomics Annual 19: 1153.

Kleimeier, Stefanie, Harald Sander, and Sylvia Heuchemer. 2013. "Financial Crises and Cross-Border Banking: New Evidence." Journal of International Money and Finance 32: 884-915.

Lim, Jamus Jerome, Sanket Mohapatra, and Marc Stocker. 2014. "Tinker, Taper, QE, Bye? The Effect of Quantitative Easing on Financial Flows to Developing Countries.” Background paper for Global Economic Prospects 2014. World Bank.

McGuire, Patrick, and Nikola Tarashev. 2006. "Tracking International Bank Flows." BIS Quarterly Review, December, 27-40.

Minoiu, Camelia, and Javier Reyes. 2011. “A Network Analysis of Global Banking: 1978-2009.” IMF Working Paper No. WP/11/74.

2013. “A Network Analysis of Global Banking: 1978-2010.” Journal of Financial Stability 9 (2): $168-84$.

Morrison, Alan, Michalis Vasios, Mungo Wilson, and Filip Zikes. 2016. "Identifying Contagion in a Banking Network." Bank of England Working Paper.

Park, Cyn-Young, and Kwanho Shin. 2017. "A Contagion through Exposure to Foreign Banks during the Global Financial Crisis.” ADB Economics Working Paper Series No. 516.

Park, Donghyun, Arief Ramayandi, and Kwanho Shin. 2016. "Capital Flows During Quantitative Easing and Aftermath: Experiences of Asian Countries." Emerging Markets Finance \& Trade 52 (4): 886-903. 


\section{Global Banking Network and Regional Financial Contagion}

This paper investigates and tests the role of regional exposures in financial contagion from advanced to emerging market economies through the global banking network using data on cross-border bilateral bank claims and liability positions. Results indicate that direct exposures of a country's own and the overall region's banking sectors to crisis-affected countries are systematically related to bank capital outflows during the global financial crisis. A further analysis suggests more favorable behavior of the same region lender toward emerging economies during crisis.

\section{About the Asian Development Bank}

ADB's vision is an Asia and Pacific region free of poverty. Its mission is to help its developing member countries reduce poverty and improve the quality of life of their people. Despite the region's many successes, it remains home to a large share of the world's poor. ADB is committed to reducing poverty through inclusive economic growth, environmentally sustainable growth, and regional integration.

Based in Manila, ADB is owned by 67 members, including 48 from the region. Its main instruments for helping its developing member countries are policy dialogue, loans, equity investments, guarantees, grants, and technical assistance.

$\mathrm{ADB}$ 